\title{
Policy and Theoretical Dimensions of Qualified Tax Partnerships
}

\author{
Bradley T. Borden*
}

\section{INTRODUCTION}

Qualified tax partnerships are arrangements that come within the federal definition of tax partnership but are not subject to partnership tax reporting and accounting rules. ${ }^{1}$ They may, however, be subject to other tax provisions. Thus, classification as a qualified tax partnership may have significant tax consequences. Nonetheless, commentary generally fails to consider this form of tax entity even though tax partnerships have been an enigma since their statutory creation. ${ }^{2}$ This oversight is unfortunate because qualified tax partnerships present fascinating policy and theoretical considerations. This Article addresses those considerations by explaining the relationship qualified tax partnerships have with other tax entities, describing the aggregate-plus tax regime that governs qualified tax partnerships, demonstrating that qualified tax partnerships lack theoretical and policy support, and finally, proposing modifications to the current regime that would alleviate the problems currently besetting qualified tax partnerships.

\footnotetext{
Associate Professor of Law, Washburn University School of Law. LL.M. and J.D., University of Florida, Fredric G. Levin College of Law; M.B.A. and B.B.A., Idaho State University. I thank Terry Cuff, Steven Dean, Brant Hellwig, Kristin Hickman, Erik Jensen, Alan Lederman, Marty McMahon, William Merkel, Robert Rhee, and Sheila Scheuerman for their helpful comments on earlier drafts of this Article; the faculty at South Carolina School of Law and Charleston School of Law for helpful comments during presentations of this Article; and Washburn University School of Law for its research support. Finally, I thank my wife Samantha and daughter Claire for their unwavering support and encouragement in this undertaking. All opinions expressed herein and any errors are my own.

1. As discussed below, the IRS coined the phrase qualified partnership in 1948. See infra note 40 and accompanying text. This Article refers to such arrangements as qualified tax partnerships.

2. See J. Paul Jackson et al., The Internal Revenue Code of 1954: Partnerships, 54 ColuM. L. REV. 1183, 1209-10 n.52 (1954) (considering whether section 761 of the 1954 Code, which codified the definition of qualified tax partnership, excludes from the definition of tax partnership only those arrangements coming within the definition of tax partnership or excludes borderline cases from the partnership tax accounting and reporting rules).
} 


\section{TAX ENTITY CLASSIFICATION SPECTRUM}

The various tax entities lay along a tax entity classification spectrum, ${ }^{3}$ ordered according to the tax law governing each type of arrangement. Arrangements disregarded by tax law are on the far left of the spectrum. ${ }^{4}$ Tax law disregards arrangements that do not come within one of the tax entity definitions. ${ }^{5}$ Disregarded arrangements include, for example: tenancies in common that are not tax partnerships; ${ }^{6}$ costsharing arrangements, such as a combined effort to dig a ditch to drain water, ${ }^{7}$ car pools and neighborhood block parties, ${ }^{8}$ co-authored law review articles; ${ }^{9}$ and the like. Disregarded arrangements are subject to aggregate taxation, where individual members of disregarded arrangements report their respective shares of the tax items of the arrangement as though the arrangement did not exist. ${ }^{10}$

Moving along the tax entity classification spectrum, the next arrangements are qualified tax partnerships. Tax law generally

3. See infra diagram accompanying notes 19-20 for an illustration of the Tax Entity Classification Spectrum. See generally Donald E. Rocap \& Russell S. Light, The Mixed-up World of Pseudo Passthroughs, 85 TAXES 323 (March 2007) (observing that several entities, including some identified in this Article, "run a rough continuum," and describing basic features of alternative tax regimes).

4. The term "tax law" as used throughout this Article refers to U.S. federal income tax law. For the purposes of this Article, an "arrangement" is any type of organized effort or combination of resources with two or more members. It does not, however, include tax trusts.

5. The tax entities include qualified tax partnerships, tax partnerships, S corporations, tax corporations, tax trusts, and estates. A non-corporate multiple-member arrangement is disregarded if it is not a tax trust or estate and it does not come within the definition of tax partnership. Thus, an arrangement that lacks a joint-profit motive, does not co-own property, or does not carry on a business would be a disregarded arrangement. See Bradley T. Borden, The Federal Definition of Tax Partnership, 43 Hous. L. REV. 925, 933 (2006) ("An arrangement that is not within one of these three definitions is a tax nothing."). This Article uses "disregarded arrangement" instead of "tax nothing" to emphasize that the tax nothings referred to herein (i.e., the disregarded arrangements) have two or more members.

6. See McShain v. Comm'r, 68 T.C. 154, 160 (1977) (holding that a co-ownership arrangement that leases property under a net lease agreement is not a tax partnership).

7. Treas. Reg. § 301.7701-1(a)(2) (as amended in 2006).

8. Such arrangements should lack the requisite joint-profit motive of a partnership. See id. One could argue, however, that a carpool creates economies of scale that provide an economic benefit to the participants. See Madison Gas \& Elec. Co. v. Comm'r, 72 T.C. 521, 562 (1979) (holding that two parties form a tax partnership when they "band together to produce with economies of scale a common product to be distributed to the members of the venture in kind"), aff'd, 633 F.2d 512 (7th Cir. 1980).

9. Because law reviews do not compensate authors, a venture to co-author a law review article should also lack the requisite joint-profit motive. See supra note 8 .

10. A tax item is any of the following: income, gain, loss, deduction, and credit. Thus, the coowners of a disregarded tenancy in common would each respectively report income from the coowned property in proportion to their ownership interest in the property and would deduct or capitalize, as appropriate, any expenditures incurred with respect to the property. 
disregards qualified tax partnerships, but recognizes them for some purposes. ${ }^{11}$ Thus, qualified tax partnerships are subject to an "aggregateplus" tax regime.

Continuing along the tax entity classification spectrum, the next arrangements are tax partnerships. Tax law originally disregarded tax partnerships. $^{12}$ Over the years, Congress began to recognize the existence of tax partnerships and created a body of partnership tax law. ${ }^{13}$ Partnership tax law attempts to disregard tax partnerships when possible to further equity, but it recognizes tax partnerships as needed to make tax laws administrable. ${ }^{14}$ Partnership taxation is an "aggregate-plus-plus" form of taxation, subjecting tax partnerships to more entity-tax principles than aggregate-plus taxation imposes on qualified tax partnerships.

Continuing along the tax entity classification spectrum, the next arrangements are $\mathrm{S}$ corporations. Like tax partnerships, $\mathrm{S}$ corporations are subject to both aggregate tax rules and entity tax rules, but in many instances the difference between tax partnership classification and $\mathrm{S}$ corporation classification is significant. ${ }^{15}$ The difference is attributable in large part to the evolution of both tax partnerships and $\mathrm{S}$ corporations.

11. See infra Part III (discussing the tax treatment of qualified tax partnerships).

12. See Tariff Act of 1913, ch. 16, § II.A., 38 Stat. 114, 166 (imposing the first income tax); see also Bradley T. Borden, Sandra Favalukes \& Todd E. Molz, A History and Analysis of the CoOwnership-Partnership Question, 106 TAX NOTES 1175, 1175-80 (2005) (discussing the history of partnership taxation).

13. See Borden, supra note 5, at 943-57 (discussing Congress's recognition of tax partnerships and its imposition of, and policy reasons for, partnership tax rules).

14. See Borden, supra note 5, at 942 ("Congress attempted to treat partner taxpayers similarly to the standard taxpayer who would conduct similar business or own property individually. To preserve partnership disregard, Congress enacted minimally intrusive rules necessitated by tax administration.").

15. Because the income and deductions of both tax partnerships and $\mathrm{S}$ corporations flow through to their owners who include such amounts in their individual computations of taxable income, these arrangements are often referred to as flow-through entities. In an operational sense, these entities and their owners are subject to similar rules. In the transactional context, however, the entities may be subject to significantly different sets of rules. For example, new members of a corporation may be taxed on contributions to corporations if they are not members of the control group. See I.R.C. § 351(a) (2000) (allowing nonrecognition to taxpayers who contribute property to a corporation in exchange for corporate stock, if immediately after the contribution the contributor is in control of the corporation). In contrast, new members of a partnership are not taxed on contributions to the partnership, unless deemed to receive a distribution due to change in individual liabilities and shares of partnership liabilities. See id. § 721(a) (providing that neither the partners nor the partnership recognize gain or loss on the contribution of property to a partnership); Id. $\S$ 752(b) (providing that a partnership is deemed to distribute cash to a partner if the partnership assumes a liability of the partner or the partner's share of partnership liabilities decreases); see also Jerald David August, Benefits and Burdens of Subchapter $S$ in a Check-the-Box World, 4 FLA. TAX REV. 287, 294-319 (1999) (comparing the different tax treatment of S corporations and tax partnerships); James S. Eustice, Subchapter S Corporations and Partnerships: A Search for the Pass Through Paradigm (Some Preliminary Proposals), 39 TAX L. REV. 345, 352-411 (1984) (comparing $\mathrm{S}$ corporations to tax partnerships). 
Whereas Congress originally disregarded partnerships and developed partnership tax law to effectively administer the taxation of partners, it carved S corporations out of the broader group of tax corporations. ${ }^{16}$ The group of tax corporations also includes $\mathrm{C}$ corporations. ${ }^{17} \mathrm{C}$ corporations (arrangements on the end of the tax entity classification spectrum opposite disregarded arrangements) are subject to entity taxation. ${ }^{18}$ Beginning with the entity tax regime and removing some of the entity taxation elements, Congress created S corporations. ${ }^{19}$ Therefore, S corporations are subject to an "entity-minus" tax regime.

The following diagram depicts the tax entity classification of multiple-member arrangements. Notice that moving from the left, the tax regime begins with aggregate taxation and moves by degree toward entity taxation.

\section{Tax Entity Classification Spectrum (Multiple-Member Arrangements)}

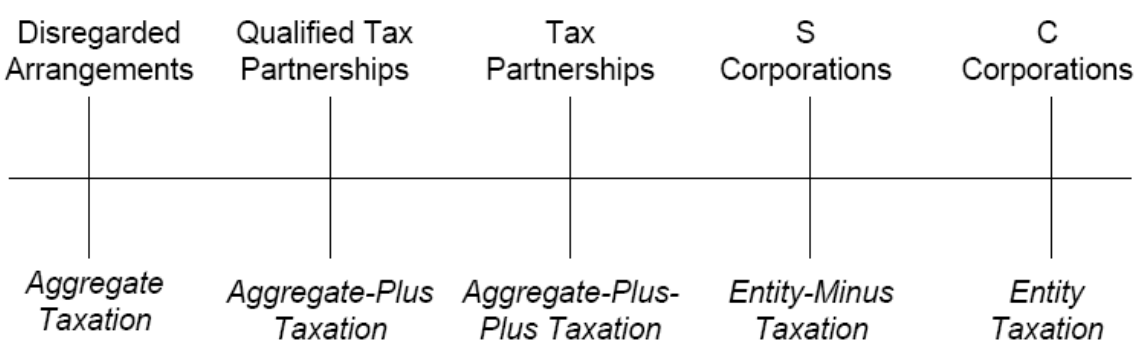

The definitions of the various arrangements determine the tax regime that will apply to a particular arrangement, and, in a waterfall fashion, the definitions place arrangements within the various classifications. First, any arrangement that comes within the definition of tax corporation falls within the tax corporation grouping. ${ }^{20}$ Second, any arrangement

16. This article uses the term "tax corporation" to refer to all entities classified as corporations under tax law. All state law corporations and other specifically identified state or federal entities are tax corporations. Treas. Reg. $\S 301.7701-2$ (b) (as amended in 2007). Other business entities may elect tax corporation classification. Id. $\S 301.7701-3(\mathrm{a})$.

17. The designation "C corporation" derives from subchapter C of the Code, the subchapter governing all tax corporations other than $\mathrm{S}$ corporations.

18. See I.R.C. § 11(a) (2000) (imposing an income tax on corporations).

19. See Id. $\S 1371$ (a) (providing that subchapter $\mathrm{C}$ applies to $\mathrm{S}$ corporations to the extent not provided for in subchapter S); see August, supra note 15 at 322-30 (discussing the history of subchapter S).

20. See Treas. Reg. $\$ 301.7701-2(b)(1)$ (as amended in 2007). 
that is not a tax corporation and comes within the definition of tax partnership falls within the tax partnership grouping. ${ }^{21}$ All other arrangements fall within the disregarded arrangement grouping. ${ }^{22}$

A parallel structure subdivides arrangements within the tax corporation grouping and the tax partnership grouping. The group of tax corporations consists of both $\mathrm{C}$ corporations and $\mathrm{S}$ corporations. Tax corporations that make valid $\mathrm{S}$ elections are $\mathrm{S}$ corporations. ${ }^{23}$ All other tax corporations are $\mathrm{C}$ corporations. The group of tax partnerships consists of both tax partnerships and qualified tax partnerships. Tax partnerships that make valid section 761 elections are qualified tax partnerships. $^{24}$ All other tax partnerships are simply tax partnerships. The following Venn diagram illustrates the parallel structure of tax partnerships and tax corporations.

\section{Tax Groupings of Multiple-Member Arrangements}

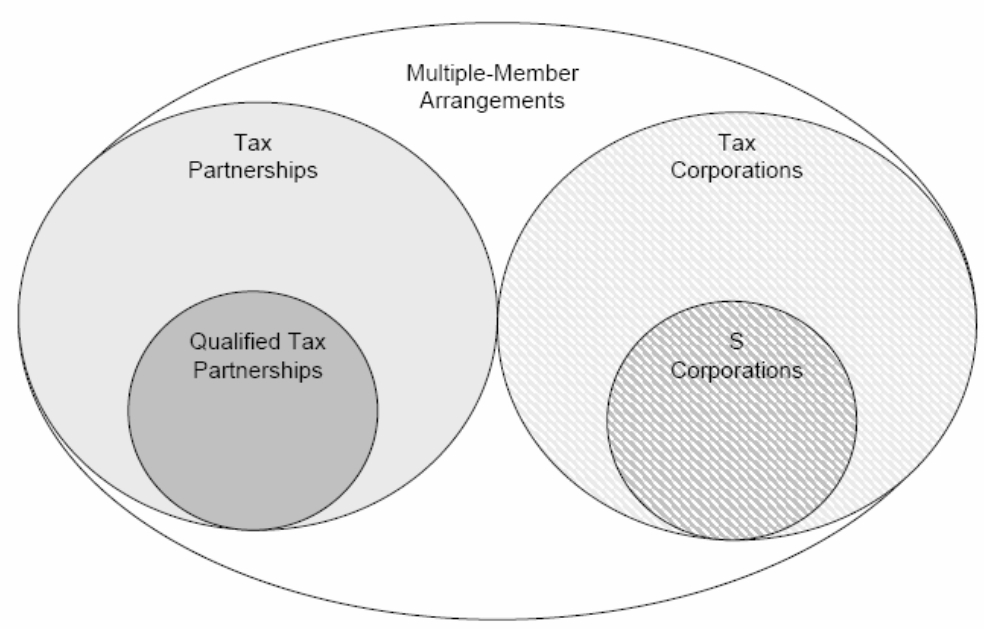

21. See Borden, supra note 5, at 937 ("An arrangement that is not a tax trust or tax corporation is a tax partnership, if within the definition of tax partnership.").

22. See supra note 5.

23. See I.R.C. § 1362(a)(1) (2000). A valid S election for this purpose is an $\mathrm{S}$ election made in accordance with the requirements in section 1362 and related regulations by an entity that is a small business corporation as defined in section 1361(b). A business entity that is not a tax corporation that makes a valid $\mathrm{S}$ election will be deemed also to have made a valid check-the-box election. See Treas. Reg. § 301.7701-3(c)(1)(v)(C) (as amended in 2007).

24. See I.R.C. § 761(a) (2000) (providing that certain tax partnerships may elect out of subchapter K); infra text accompanying note 40 (discussing the origin and use of the term "qualified tax partnership"). All section references are to the Internal Revenue Code of 1986 as amended, unless stated otherwise. 
Because the definitions of the various arrangements determine an arrangement's grouping and applicable tax regime, the definitions are important. The definitions of tax corporation and $\mathrm{S}$ corporation are relatively clear. $^{25}$ Indeed, commentators have devoted significant attention to tax corporations, entity taxation, and the related policy issues. $^{26}$ Similarly, commentators have discussed S corporations, ${ }^{27}$ and legislative history describes that the purpose of $\mathrm{S}$ corporations is to allow small business owners to take advantage of the liability protection of a corporation without double taxation. ${ }^{28}$ Even though this purpose helps explain S corporations, it does not encompass the entire definition. ${ }^{29}$ The requirements in the Code make the definition of $\mathrm{S}$ corporation more clear. $^{30}$

In contrast to the established definitions of tax corporation and $\mathrm{S}$ corporation, the definition of tax partnership is not clear. ${ }^{31}$ Because qualified tax partnerships are a subgroup of the tax partnership group, the definition of qualified tax partnership is a fortiori unclear. Furthermore, a relatively small amount of commentary has been devoted to the definitions of tax partnership and qualified tax partnership, or the policy underlying aggregate-plus taxation. ${ }^{32}$ The lack of attention devoted to

25. See Treas. Reg. $\S 301.7701-2$ (b) (as amended in 2007) (listing the entities that are tax corporations); id. $\S 301.7701-3$ (a) (providing that an entity that is not classified as a tax corporation under section 301.7701-2(b) may elect to be a tax corporation); I.R.C. $\S 1361$ (2000) (listing the requirements that a corporation must satisfy to be make a valid S election); I.R.C. $§ 1362$ (2000) (providing rules for making the $\mathrm{S}$ election).

26. Borden, supra note 5, at 934 n.30, 935 n.33.

27. See, e.g., Thomas C. Plowden-Wardlaw, Election of Certain Small Business Corporations as to Taxable Status: Technical Amendments Act of 1958 Internal Revenue Code Subchapter S, 23 ALB. L. REV. 245 (1959) (discussing the technical elements of subchapter S immediately following the 1958 amendments and presenting some pitfalls of failing to meet the requirements of subchapter S); Walter D. Schwidetzky, Is It Time to Give the S Corporation a Proper Burial?, 15 VA. TAX REV. 591, 637 (1996) (discussing S Corporations generally and positing that "the S corporation is a vehicle with little continuing viability").

28. See S. REP. NO. 85-1983, at 87 (1958) (stating that the provision is a "substantial benefit to small corporations" because a "double" tax is removed).

29. See Schwidetzky, supra note 27, at 595 ("Little in the legislative history of the S corporation reveals why these restrictions were chosen.").

30. "Code" refers to the Internal Revenue Code of 1986, as amended.

31. See Borden, supra note 5, at 975 (identifying ten different tests that Congress, courts, Treasury, and the IRS use to determine whether an arrangement is a tax partnership).

32. Professor Martin J. McMahon, Jr. wrote a significant piece about production qualified tax partnerships, providing an in-depth analysis of arrangements that are eligible to make a section 761 election, the eligibility requirements for making such an election, and the effect of making such an election. See Martin J. McMahon, Jr., The Availability and Effect of Election Out of Partnership Status Under Section 761(a), 9 VA. TAX REV. 1 (1989); see also Noah S. Baer, Selling a Partnership Interest After an Election Out of Subchapter K, 9 J. P'SHIP TAX'N 229, 230-34 (1992) (discussing the history and purpose of qualified tax partnerships); Bradley T. Borden, Revisiting the Federal Tax Definition of Partnership and the $\$ 761(a)(1)$ Election in the TIC Environment, 47 TAX MGM'T 
the purposes of tax partnerships and qualified tax partnerships, and the policy underlying aggregate-plus taxation, compounds the difficulty of clearly defining each arrangement. ${ }^{33}$ The neglect of these issues is problematic because a significant percentage of all arrangements are either tax partnerships or qualified tax partnerships. ${ }^{34}$

The lack of commentary about qualified tax partnerships may stem from a perception of their relative significance. Entity taxation imposes double taxation on shareholders - a continuous tax concern. Business owners and the government can predict and understand the outcome of double taxation. Both know that business owners will generally pay more tax under double taxation than they would in its absence. Because of the general interest in double taxation, the definition of tax corporation, which determines the type of arrangements that will be subject to entity taxation, attracts attention.

On the other hand, aggregate-plus taxation does not impose double taxation. The tax issues that arise from tax partnership classification tend to be episodic, often arising only when one of a limited class of transactions occurs. ${ }^{35}$ Often, taxpayers and the IRS cannot predict the type of transaction that will implicate tax partnership classification. Without knowing this information, neither taxpayers nor the IRS can predict ex ante the position either will take with respect to the classification of a tax partnership. ${ }^{36}$ Nonetheless, the innumerable

MEMo 51, 52-57 (Feb. 6, 2006) (focusing on the definition of tax partnership and investment qualified tax partnership). A few articles have struggled with the definition of tax partnership. See, e.g., Borden, supra note 5, at 1008-26 (providing an in-depth analysis of tax partnerships). See generally Timothy M. Larason, "Tax Partnerships" Offer Greater Benefits as Entities for Oil and Gas Operations, $60 \mathrm{~J}$. TAX'N 30 (1984) (discussing the benefits of tax partnership classification).

33. See Borden, supra note 5, at 927 ("[A]lthough the federal definition of tax partnership has been at issue in over 150 statutes, cases, regulations, and rulings, it is the rare occasion that tax policy has governed attempts to define tax partnership."); Bradley T. Borden, A Catalogue of Legal Authority Addressing the Federal Definition of Tax Partnership, in TAX PLANNING FOR DOMESTIC \& Foreign PARTNERSHIPS, LLCS, JOINT VENTURES \& OTHER STRATEGIC AllianCES 445, 445-72 (Louis S. Freeman \& Clifford M. Warren eds., 2007) (listing and briefly describing the legal authority that has addressed the definition of tax partnership).

34. See Susan Pace Hamill, The Story of LLCs: Combining the Best Features of a Flawed Business Tax Structure, in Business TAX STORIES 295, 297-98 \& nn.13-14 (Steven A. Bank \& Kirk J. Stark eds., 2005) (summarizing statistics of 2001 tax entity filings that show 2,132,000 tax partnership filings and 5,135,591 tax corporation filings). That data most likely does not reflect the number of qualified tax partnerships in existence because such entities likely filed a tax return to make the section 761 election and then did not file again. Therefore, data probably does not exist to show the actual number of qualified tax partnerships in existence.

35. See Borden, supra note 5, at 957-69 (identifying several transactions affected by tax partnership classification: the characterization of gain or loss on the disposition of property, the person to whom tax items should be allocated, the tax effects upon the formation of an arrangement, the nature of property transferred, the effect liabilities have on the basis of property, and whether certain costs must be capitalized).

36. See Borden, supra note 33. 
transactions that occur each year, and the costs incurred to contend the issue of tax partnership classification, make the definition of tax partnership important and worthy of greater attention. ${ }^{37}$ The tax significance of qualified tax partnership classification is similarly largely episodic but can be very important. Despite the significance of both issues, they receive scant attention.

An earlier article explored the definition of tax partnership. ${ }^{38}$ This Article's focus is farther to the left, examining the definition of qualified tax partnership. The Article first explains the relationship between disregarded arrangements, qualified tax partnerships, and tax partnerships - a relationship that is often misunderstood. This explanation establishes the separate identity of qualified tax partnerships. The discussion then focuses on the tax treatment of qualified tax partnerships. Understanding that treatment sets the stage for examining whether policy supports the concept and current definition of qualified tax partnerships. This examination reveals that policy does not support qualified tax partnerships. One way to remedy this problem is to amend the definition of tax partnership, as recommended in the earlier article. ${ }^{39}$ In the absence of such remedy, the definition of qualified tax partnership plays an important role. That definition exempts certain tax partnerships from the tax partnership rules. Thus, if lawmakers do not modify the definition of tax partnership, Treasury should modify the definition of qualified tax partnership to better reflect changes that have occurred since its origin some thirty-five years ago and, more importantly, sound tax policy. The Article also exposes deficiencies in the current aggregate-plus tax regime and proposes modifications that would remove the deficiencies and reflect sound tax policy.

37. Additionally, the distinction between aggregate-plus-plus taxation and entity-minus taxation deserves more attention.

38. See Borden, supra note 5.

39. See Borden, supra note 5, at 1028 ("Based on the above analysis and retaining the taxentity default rule, a tax partnership is two or more persons, at least one of whom provides significant services, who have (or will have) common gross income. This proposed definition incorporates all of the tests that pass policy scrutiny and are necessary for a workable definition of tax partnership, and it disposes of the tests that fail policy scrutiny."). That proposed definition would not include the definition of production qualified tax partnerships because such arrangements do not have a common gross income. Id. at 1017-23 (discussing the inadequacies of the joint-profit test used to analyze co-owned joint-production arrangements). It would not include investment qualified tax partnerships because no co-owner in such an arrangement provides significant services. $I d$. at 1012-15, 1024-26 (discussing the strength of the degree-of-activity test, the type-of-activity test, and the source-of-activity test used to determine whether a co-ownership arrangement is a tax partnership). See also infra Part VI.A. (discussing the definition-narrowing proposal). 


\section{THE THEORETICAL UNDERPINNINGS OF QUALIFIED TAX PARTNERSHIP CLASSIFICATION}

The IRS coined the phrase "qualified partnership" in $1948 .^{40}$ It ruled at that time that a particular oil and gas co-owned joint-production arrangement was a tax partnership but that it did not have to follow the partnership tax accounting and reporting rules. ${ }^{41}$ An earlier regulation provided that co-owned joint-production arrangements are not necessarily tax partnerships. ${ }^{42}$ Any arrangement that was not a tax partnership under that earlier regulation would not have been subject to partnership tax accounting and reporting rules and should have been disregarded for all other tax purposes. ${ }^{43}$ The IRS's change of position regarding co-owned joint-production arrangements was inspired by Congress's enactment of a broad definition of tax partnership. ${ }^{44}$ Following the enactment of that broad definition, which included joint ventures, the IRS was obligated to rule that co-owned joint-production arrangements were tax partnerships. ${ }^{45}$ Nonetheless, it ruled that such arrangements should not be subject to the partnership tax accounting and reporting rules, ${ }^{46}$ thus creating qualified tax partnerships. Congress has since recognized qualified tax partnerships, ${ }^{47}$ and they remain a fixture of the U.S. tax system.

40. See I.T. 3930, 1948-2 C.B. 126, 129 ("The Bureau, under [I.T. 2749 and I.T. 2785] has consistently treated all such operating agreements as creating qualified partnerships ...." (emphasis added)). Some commentators have picked up on that usage. See, e.g., Baer, supra note 32, at 230 ("With I.T. 3930, the Service determined to divide those agreements into associations and "qualified partnerships."'); Borden, supra note 5, at 984 ("Joint profit is an element of the substantive-law test, but it has found special application defining qualified tax partnerships. Qualified tax partnerships are those arrangements that meet the definition of tax partnership but are not required to follow the partnership tax accounting and reporting rules."). This Article uses "qualified tax partnership" instead of "qualified partnership," as used originally by the IRS, because it uses the term "tax partnership" to refer to arrangements tax law recognizes as partnerships.

41. See I.T. 3930, at 128-29. "Co-owned joint-production arrangements are those whose members co-own property and pool resources to produce something from the co-owned property." Borden, supra note 5, at 984.

42. See Trust No. 5833, Sec.-First Nat. Bank of L.A. v. Welch, 54 F.2d 323, 328 (9th Cir. 1931) (“"Co-owners of oil lands engaged in developing the property through a common agent are not necessarily partners."”) (citing Regulations 74, Art. 1317 (1931)).

43. Borden, supra note 5 , at $957,969$.

44. See Revenue Act of 1932, ch. 209, § 1111(a)(3), 47 Stat. 169, 289 (redefining tax partnership).

45. See I.T. 2749, 8-1 C.B. 99, 99-100 (1934) (stating co-ownerships of oil and gas leases are joint ventures); Borden, supra note 5, at 986 .

46. I.T. $2785,8-1$ C.B. $96,96-97$ (1934).

47. See I.R.C. § 761(a) (2000). 


\section{A. Definitional Groupings of Non-Corporate Arrangements}

Qualified tax partnerships are one of three non-corporate arrangements. The relationship of the three non-corporate arrangements (the three arrangements on the left end of the tax entity classification spectrum $)^{48}$ is analogous to that of a family of Russian nesting dolls. In the case of non-corporate arrangements, within the broad group of noncorporate arrangements nests the smaller group of tax partnerships, and within the group of tax partnerships nests the even smaller group of qualified tax partnerships. The following Venn diagram depicts the nesting relationship of the three groups of non-corporate arrangements.

\section{Groupings of Non-Corporate Arrangements}

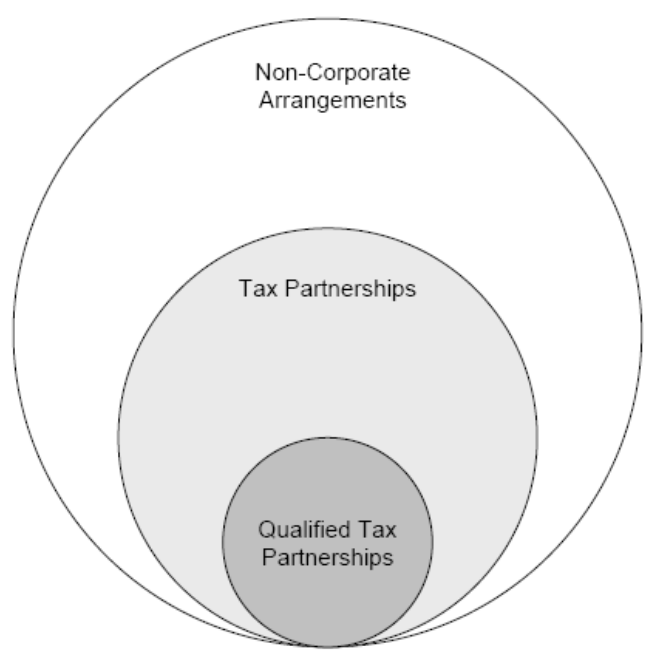

This relationship helps explain the significance of the definitions of tax partnership and qualified tax partnership. The area outside the tax partnerships circle and within the non-corporate arrangements circle represents disregarded arrangements. ${ }^{49}$ The line separating tax partnerships from disregarded arrangements is the definition of tax

48. See supra diagram accompanying notes 19-20.

49. As explained above, arrangements that do not come within the definition of tax corporation are either disregarded arrangements, tax partnerships, or qualified tax partnerships. See supra text accompanying notes 20-24. Because the diagram identifies three types of non-corporate arrangements, and two of the types are defined, those arrangements that are neither tax partnerships nor qualified tax partnerships are disregarded arrangements. 
partnership. ${ }^{50}$ The line separating tax partnerships from qualified tax partnerships is the definition of qualified tax partnership. The definitions of tax partnership and qualified tax partnership therefore separate the three types of arrangements.

From a definitional perspective, the definition of tax partnership creates a group of arrangements that is smaller than the total group of non-corporate arrangements. The definition of tax partnership does this by adding criteria to the definition of non-corporate arrangements. For example, the definition of non-corporate arrangement might be: "any arrangement that does not come within the definition of tax corporation." 51 This broad definition would include a simple coownership of raw land, an unincorporated thousand-person law firm, a co-owned joint-production arrangement, and an infinite number of other arrangements.

The definition of tax partnership creates a narrower group of arrangements that is a subset of non-corporate arrangements. It creates that smaller group by adding to the definition of non-corporate arrangement the requirement that the arrangement "conduct some activity and divide the profits among its members." excludes from the group of tax partnerships any non-corporate arrangement that does not conduct some activity or that has no profits. An example of such an arrangement would be a mere cost-sharing arrangement under which the members join together to dig a ditch to drain their adjacent properties. ${ }^{53}$ Although a mere cost-sharing arrangement is a non-corporate arrangement that conducts activities, it provides no profits to divide among its members. Thus, it does not come within the definition of tax partnership.

The definition of qualified tax partnership creates a group of noncorporate arrangements that is even narrower than the group of tax partnerships. The definition does this by adding requirements to the

50. See supra text accompanying note 221 .

51. Non-corporate, multiple-member arrangement is not defined in tax law. Such arrangements do, however, exist, as this discussion demonstrates.

52. Because there is no exact definition of tax partnership, this is an example of what the definition might be. The substantive law definition focuses on business activity and sharing of profit. Sharing of profit is not a tax term or concept so it has little utility in the tax context. See Borden, supra note 5, at 1017-23. As discussed above, the focus on business activity also has limited utility. A potentially workable definition would focus on the number of members, whether the members contribute services, and would consider the control of gross income instead of profit sharing. See, e.g., Borden, supra note 5, at 1028 (proposing the following definition: "a tax partnership is two or more persons, at least one of whom provides significant services, who have (or will have) common gross income").

53. Treas. Reg. $\S 301.7701-1(a)(2)$ (as amended in 2006). 
definition of tax partnership. For example, the definition of qualified tax partnership might add to the definition of tax partnership the requirement that the members of the arrangement co-own the property and take the arrangement's product in kind. ${ }^{54}$ This additional requirement creates a group of non-corporate arrangements that is smaller than, and contained within, the group of tax partnerships. The following Venn diagram illustrates the definitional progression of non-corporate arrangements.

\section{Definitional Groupings of Non-Corporate Arrangements (Tax Partnership and Qualified Partnership Subsets)}

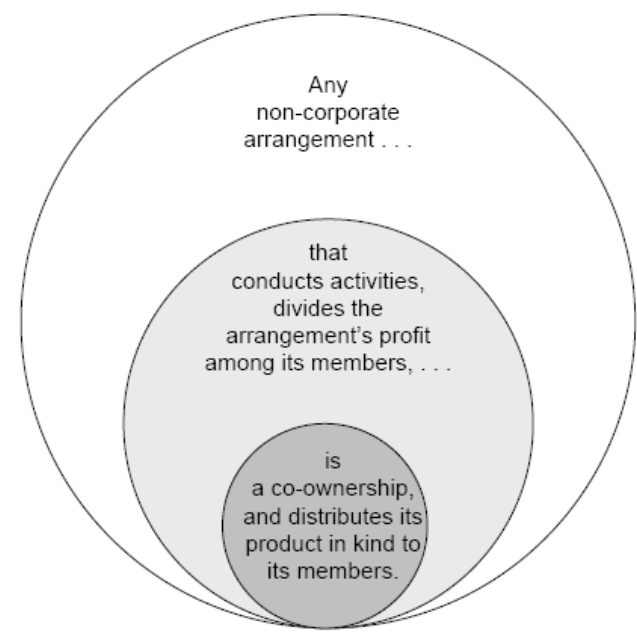

Although this structure appears to be simple, it is not necessarily intuitive. Recall that qualified tax partnerships lay between disregarded arrangements and tax partnerships on the Tax Entity Classification Spectrum. ${ }^{55}$ The Tax Entity Classification Spectrum groups arrangements according to the applicable tax regime. The entity groupings these Venn diagrams represent are based upon the definitions of the arrangements. As stated above, the definitions of group arrangements determine the tax regime that applies to a specific arrangement (for example, $\mathrm{S}$ corporations are subject to entity-minus taxation and the definition of $\mathrm{S}$ corporation determines whether an

54. See id. § 1.761-2(a)(3) (as amended in 1995) (requiring the members of a joint-production arrangement to co-own the arrangement's property, reserve the right to take the arrangement's product in kind, and not jointly sell the arrangement's product to come within the definition of production qualified tax partnership).

55. See supra diagram accompanying notes $19-20$. 
arrangement is an S corporation). ${ }^{56}$ To fully appreciate the relationship of arrangements, one must keep the different groupings separate.

Attempting to group non-corporate arrangements definitionally according to the applicable tax regime produces an unworkable structure. Such alternative definitional grouping would diminish the utility of the section 761 elections, which define qualified tax partnerships and exempt certain tax partnerships from subchapter $\mathrm{K}^{57}$ For example, if the definition of qualified tax partnership expanded the definition of tax partnership, tax partnerships would become a subset of qualified tax partnerships, or qualified tax partnerships would become a separate subset of non-corporate arrangements outside the tax partnership subset. Either interpretation is unworkable. The following Venn diagram represents the first unworkable alternative interpretation of the relationship: tax partnerships as a subset of qualified tax partnerships.

\section{First Unworkable View of Groupings of Non-Corporate Arrangements}

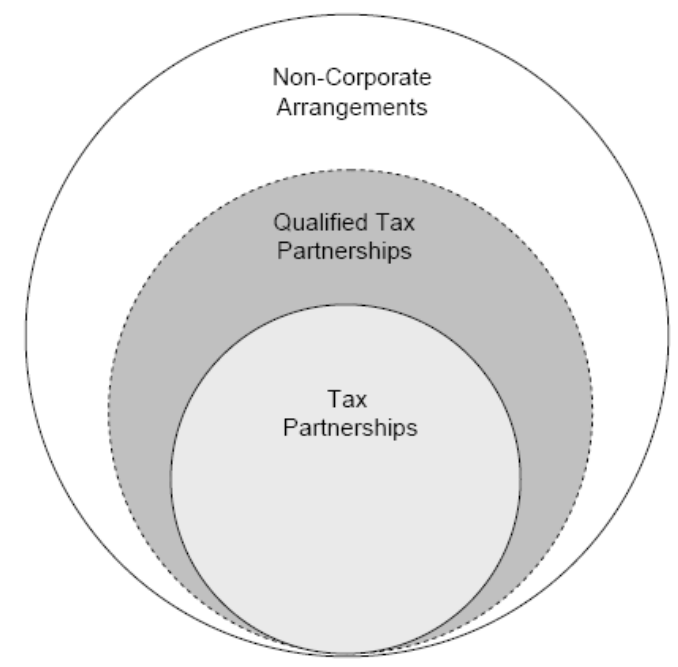

The second unworkable interpretation of the relationship of tax partnerships and qualified tax partnerships presents qualified tax partnerships as a subset of non-corporate arrangements outside the tax

56. See supra text accompanying notes 10-12.

57. See infra text accompanying notes 59-62. 
partnership subset. The following Venn diagram presents that unworkable interpretation.

\section{Second Unworkable View of Groupings of Non-Corporate Arrangements}

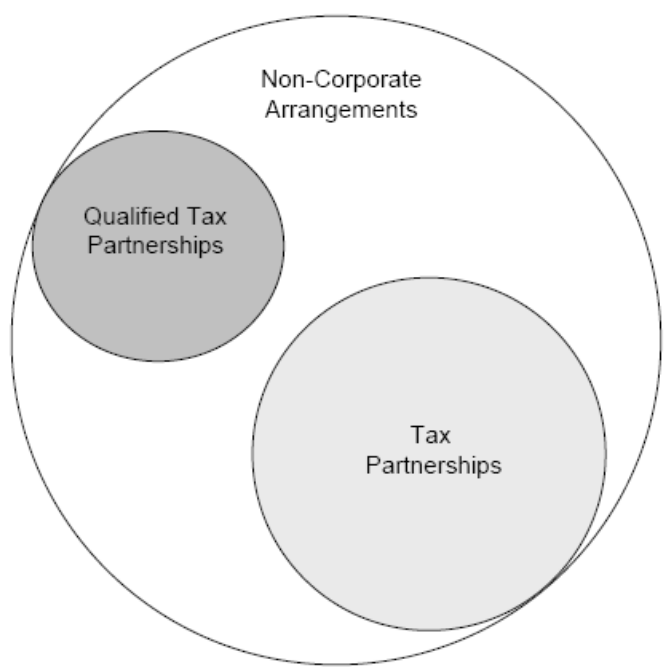

These two interpretations are unworkable because an arrangement could elect out of subchapter $\mathrm{K}$ only if subchapter $\mathrm{K}$ applied to such arrangement. The gateway to subchapter $\mathrm{K}$ is the definition of tax partnership. ${ }^{58}$ The only type of arrangement that would have occasion to elect out of subchapter $\mathrm{K}$ would be an arrangement that is subject to subchapter K. Therefore, any interpretation of the relationship that does not identify qualified tax partnerships as a subset of tax partnerships is incorrect and unworkable. Understanding this relationship is key to analyzing the definition of qualified tax partnership. The definition of qualified tax partnership that Congress (through statute) and Treasury (through regulation) have established must create a group of arrangements that are a subset of tax partnerships.

58. See Borden, supra note 5, at 960 ("The definition of tax partnership also determines whether subchapter K applies."). 


\section{B. Definitional Construct of Qualified Tax Partnerships}

The requirements for section 761 election constitute the definition of qualified tax partnership. A qualified tax partnership is any tax partnership that makes a valid election under section $761 .{ }^{59}$ Thus, an exploration of the definition of qualified tax partnership requires an examination of the section 761 election requirements. Tax partnerships may consider one of three elections: (1) the election to be an investment qualified tax partnership; ${ }^{60}$ (2) the election to be a production qualified tax partnership; ${ }^{61}$ and (3) the election to be an underwriting qualified tax partnership. ${ }^{62}$ This Article focuses on the first two types of qualified tax partnerships. ${ }^{63}$ In addition to satisfying the specific requirements of each definition, the arrangement must be able to determine its income without computing partnership taxable income. ${ }^{64}$ With that in mind, the following discussion considers the two definitions of qualified tax partnership.

\section{Investment Qualified Tax Partnership}

An investment qualified tax partnership is "an unincorporated organization ... a availed of . . . for investment purposes only and not for the active conduct of a business." "65 Treasury regulations amplify this definition to be an arrangement "[w]here the participants in the joint purchase, retention, sale, or exchange of investment property: [(1)] [o]wn the property as coowners, [(2)] [r] eserve the right separately to take or dispose of their shares of any property acquired or retained, and [(3)]

59. See Borden, supra note 32, at 58-59 (describing actual and deemed elections); see also McMahon, supra note 32, at 21-30 (discussing the eligibility and procedure for making an election under section 761(a)(2)).

60. I.R.C. $\$ 761(a)(1)(2000)$

61. Id. $\S 761(\mathrm{a})(2)$.

62. See id. $\S 761(a)(3)$ (providing that an underwriting qualified tax partnership is "an unincorporated organization ... availed of ... by dealers in securities for a short period for the purpose of underwriting, selling, or distributing a particular issue of securities, if the income of the members of the organization may be adequately determined without the computation of partnership taxable income").

63. Part of the reason for narrowing the focus of this Article is that Treasury has supplemented the statutory definition of investment qualified tax partnerships and production qualified tax partnerships with regulatory requirements. See Treas. Reg. § 1.761-2(b)(2), (3) (as amended in 1994).

64. See I.R.C. $§ 761(a)(2000)$.

65. Id. $\S 761(\mathrm{a})(1)(2000)$. 
[d]o not actively conduct business." $" 66$ Because no case law (and little commentary) addresses qualified tax partnerships, determining the scope of the definition requires some speculation. Perhaps the definition applies to certain types of investment clubs, a possibility that the IRS has considered in two rulings. ${ }^{67}$ Members of such arrangements contribute cash, co-own investments, and only engage in investment activities. ${ }^{68}$ Thus, such arrangements appear to satisfy the definition of investment qualified tax partnership.

Certain rental real estate co-ownership arrangements should also come within the definition of investment qualified tax partnership. Owning and renting property under a triple-net lease is not a business activity because the owners merely collect rent from the property, which is not sufficient to be a business activity. ${ }^{69}$ Also, holding real estate for

66. Treas. Reg. $\S 1.761-2(a)(2)$ (as amended in 1995) (prohibiting further members of the arrangement from "authoriz[ing] some person or persons acting in a representative capacity to purchase, sell, or exchange such investment property, although each separate participant may delegate authority to purchase, sell, or exchange his share of any such investment property for the time being for his account, but not for a period of more than a year").

67. Two non-section 761(a)(1) rulings identify investment clubs to which section 761(a)(1) may apply. In Revenue Ruling 75-523, a group of investors formed an investment club that was a tax partnership. 1975-2 C.B. 257. The members of the investment club contributed only cash to the club, co-owned the club's investments, and reserved a right to separately take or dispose of their respective shares of the investments. Id. The club's income derived solely from taxable dividends, interest, and gains from the sale of the securities. The investment club incurred expenses for items such as "postage, stationery, safe deposit box rentals, bank charges, fees for accounting and investment services, rent, and utility charges." Id. The IRS ruled that the investment club did not carry on a trade or business within the definition of section 162, even though it "is considered to have an objective to carry on business for purposes of section 7701." Id. See also I.R.S. Gen. Couns. Memo. 33,469 (March 28, 1967) (advising on the issues in Revenue Ruling 75-523).

In Revenue Ruling 75-525, the IRS ruled that income from an investment club was not selfemployment income under section 1402 because the partnership's activities were "limited to investment in savings certificates and collection of interest" on those investments, which are not sufficient to create a trade or business required under section 1402. 1975-2 C.B. 350. The arrangements in Revenue Rulings 75-523 and 75-525 had section 212 investment activity, but no section 162 trade or business activity. Id.; Rev. Rul. 75-523, 1975-2 C.B. 257. Section 761(a)(1)'s language regarding investment purposes only and disallowing active trade or business indicates that the investment clubs described in the rulings should qualify for the election.

68. Investment activities would be those activities that give rise to a deduction under section 212, but not under section 162. Id.

69. See, e.g., Grier v. United States, 120 F. Supp. 395, 398 (D. Conn. 1954) (holding that leasing property for a long period to a single tenant with minimal effort by the lessor is not a trade or business), aff'd, 218 F.2d 603 (2d Cir. 1955); Neill v. Comm'r, 46 B.T.A. 197, 198 (1942) ("[T]he mere ownership of property from which income is drawn does not constitute the carrying on of business within the purview of [section 162].") (citing McCoach v. Minehill \& Schuylkill Haven R.R. Co., 228 U.S. 295 (1913); Stafford Owners, Inc. v. United States, 39 F.2d 743 (1930)); see also Gorod v. Comm'r, 42 T.C.M. (CCH) 1569, 1572 (1981) (holding that a person who advertised rental property and kept it in rental condition, but could not rent the property, held the property for production of income and could deduct costs under section 212). 
speculative purposes is not a trade or business. ${ }^{70}$ Co-ownership arrangements of such property should be deemed investment qualified tax partnerships if they are tax partnerships and make a valid section 761 election. $^{71}$ Co-owners who provide management services to tenants probably conduct business activity and thus could not come within the definition of investment qualified tax partnership. ${ }^{72}$ Those few types of arrangements appear to be the universe of investment qualified tax partnerships.

\section{Production Qualified Tax Partnership}

A production qualified tax partnership is "an unincorporated organization ... availed of . . . for the joint production, extraction, or use of property, but not for the purpose of selling services or property produced or extracted." ${ }^{\prime 3}$ Treasury regulations provide that members of co-owned joint-production arrangements may qualify for the election if they "[(1)] [o]wn the property as coowners, [in a form granting them] exclusive operating rights, [(2)] [r] eserve the right separately to take in kind or dispose of their shares of any property produced, extracted, or used, and [(3)] [d]o not jointly sell services or the property produced or extracted ...."74 This definition applies to co-owned joint-production

70. See Harris v. Comm'r, 37 T.C.M. (CCH) 1370, 1374 (1978) (holding that trips to maintain an investment property were deductible, but trips that were unnecessary for maintenance were not).

71. Such arrangements may not, however, be tax partnerships under the type-of-activity test. See Rev. Rul. 75-374, 1975-2 C.B. 261 (stating that "[t]he furnishing of customary services in connection with the maintenance and repair of the apartment project will not render a coownership a partnership").

72. See, e.g., Pinchot v. Comm'r, 113 F.2d 718, 719 (2d Cir. 1940) ("What was done was more than the investment and re-investment of funds in real estate. It was the management of the real estate itself for profit .... It necessarily involved alterations and repairs commensurate with the value and number of buildings cared for and such transactions as were necessary constitute a recognized form of business. The management of real estate on such a scale for income producing purposes required regular and continuous activity of the kind which is commonly concerned with the employment of labor; the purchase of materials; the making of contracts; and many other things which come within the definition of business . . ."); Cecil v. Comm'r, 100 F.2d 896, 901 (4th Cir. 1939) ("The taxpayer was not investing fresh capital in a new enterprise but was endeavoring to make presently owned property productive of new income.”); Francis v. Comm'r, 36 T.C.M. (CCH) 704 (1977) (holding that property owner was in the trade or business of operating a rental apartment complex); Hazard v. Comm'r, 7 T.C. 372 (1946) (holding that the property owner held rental property for use in a trade or business, even though business activity appears to have been minimal).

73. I.R.C. $\S 761(\mathrm{a})(2)(2000)$.

74. Treas. Reg. $\S 1.761-2(a)(3)$ (as amended in 1995). A limited exception to the third requirement allows "each separate participant [to] delegate authority to sell his share of the property produced or extracted for the time being for his account, but not for a period of time in excess of the minimum needs of the industry, and in no event for more than 1 year ..." $\$ 1.761-2(a)(3)(i i i)$. Additional rules apply to entities that produce natural gas under a joint operating agreement. $\S$ 1.761-2(a)(3). Also, an entity that has a principal purpose of "cycling, manufacturing, or processing 
arrangements, which apparently could include oil and gas jointproduction arrangements, ${ }^{75}$ co-mining arrangements, ${ }^{76}$ and electrical power co-generation arrangements, ${ }^{77}$ among others.

Production qualified tax partnerships have an identifiable history and purpose that shed general light on qualified tax partnerships. The definition of production qualified tax partnership appears to be a codification of the IRS's early joint-profit test. ${ }^{78}$ Prior to the enactment of the statutory definition of tax partnership, Treasury understood certain oil and gas co-owned joint-production arrangements to be beyond the scope of the definition of a tax partnership. ${ }^{79}$ In 1932, Congress defined partnership as any "syndicate, group, pool, joint venture, or other unincorporated organization, through or by means of which any business, financial operation, or venture is carried on, and which is not, within the meaning of this Act, a trust or estate or a corporation." 80 Courts, Treasury, and the IRS have interpreted this definition broadly. ${ }^{81}$

Following the enactment of the statutory definition of tax partnership, Treasury withdrew its earlier interpretation of the definition of tax partnership. ${ }^{82}$ Later, the IRS ruled that co-owned joint-production arrangements come within the definition of tax partnership but are not

for persons who are not members of the organization" cannot elect out of subchapter K. Id.

75. See Rev. Rul. 65-118, 1965-1 C.B. 30-31 (ruling that an oil co-owned joint-operating arrangement that made a valid section 761 election remained subject to some Code provisions outside of subchapter K).

76. See Rev. Rul. 83-129, 1983-2 C.B. 105 (noting that an "election under section 761(a) excluded the [co-mining] partnership from the provisions of subchapter K”).

77. See Rev. Rul. 68-344, 1968-1 C.B. 569, 571-72 (ruling that a co-owned joint power production arrangement was a tax partnership eligible to make the section 761(a)(2) election). See also Madison Gas \& Elec. Co. v. Comm'r, 633 F.2d 512, 514 (7th Cir. 1980) (ruling that the arrangement was a tax partnership without considering whether its section 761 election was valid).

78. See Borden, supra note 5, at 990 ("The . . joint-profit test is preserved in section 761(a)(2), which allows certain arrangements that co-own property and distribute production from the property in kind to its members to elect out of subchapter K."').

79. See Trust No. 5833, Sec.-First Nat'l Bank of L.A. v. Welch, 54 F.2d 323, 328 (9th Cir. 1931) ("Co-owners of oil lands engaged in developing the property through a common agent are not necessarily partners.” (citing Regulations 74, Art. 1317 (1931))).

80. Revenue Act of 1932, ch. 209, § 1111(a)(3), 47 Stat. 289. That definition largely survives today in sections 7701(a)(2) and 761(a).

81. See, e.g., Bussing v. Comm'r, 88 T.C. 449, 460 (1987) (stating that the federal tax definition of partnership "is broader in scope than the meaning of the term at common law"); Kelly v. Comm'r, 29 T.C.M. (CCH) 1090, 1101 (1970) (observing that the definition of tax partnership is broader than state-law definition); Baughn v. Comm'r, 28 T.C.M. (CCH) 1447, 1455 (1969) (stating that "the statutory definition of $[\operatorname{tax}]$ partnership is . . . broader . . than the common law meaning" of partnership).

82. Regulations 77 did not include Art. 1317. See also I.T. 2749, XIII-1 C.B. 99, 100 (1934) ("The omission of the provisions of article 1317 of Regulations 74 from Regulations 77 .. was occasioned by the definition of a partnership contained in section 1111(a)(3) of the Revenue Act of 1932 . . which definition did not appear in the Revenue Act of 1928."). 
required to follow the partnership tax accounting and reporting rules (in other words, they are qualified tax partnerships). ${ }^{83}$ Under the IRS's joint-profit test, co-owned joint-production arrangements that distribute their entire product in kind to their members were qualified tax partnerships. ${ }^{84}$ The statutory definition of production qualified tax partnership codifies the IRS's joint-profit test. ${ }^{85}$

\section{Effect of Protective Elections}

Every arrangement is either a tax partnership or not. ${ }^{86}$ The inability, however, to precisely determine the classification of arrangements in certain situations gives rise to protective section 761 elections. In many situations, the arrangement's classification is clear. For example, an incorporated arrangement is a tax corporation, ${ }^{87}$ and therefore not a tax partnership. A two-member unincorporated law firm comes within the definition of tax partnership, ${ }^{88}$ so it would be a tax partnership. A mere expense-sharing arrangement is not a tax partnership $;{ }^{89}$ it is a disregarded arrangement. The proper classification of several non-corporate arrangements is unclear, however, because the definition of partnership is unclear. The only way to determine the classification of such

83. See I.T. 2785, XIII-1 C.B. 96 (1934) (discussing the "coownership of oil and gas lands and leases"). The ruling allowed the operating co-owner to file Form 1065 and an attached schedule provided by the IRS. Id. The schedule was required to show "the [(1)] total working interest, [(2)] names and addresses of the coowners, [(3)] the percentage of each coowner's interest in the coownership, [(4)] total costs and expenses billed each coowner with respect to drilling for and producing ... oil and gas, and [(5)] the total revenue credited in those cases where the operating coowner distributed revenue to the other coowners (by way of credit or cash) from the sale or other distribution of the coowners' oil and gas." Id. at 96-97.

84. See I.T. 3930, 1948-2 C.B. 126, 129 (“As such agreements commonly allow the participants to take their shares of the mineral in kind (or provide for the sale of the shares of the respective participants for their individual accounts under revocable agency powers), the sale of the mineral, even though made by the operator, is a sale by or on behalf of the individual participants. In such cases there is no joint profit contemplated or realized by the associates ... [I]t is held that the participants, through the partnership thus created, individually own depletable economic interests in the oil and gas in place and must report the proceeds therefrom as their income.").

85. See Borden, supra note 5, at 990-91 (discussing the codification of the joint-profit test).

86. This statement is true under the law of the excluded middle. See A.R. LACEY, A Dictionary OF PHILOSOPHY 101 (3d ed., Routledge 1996) ("Traditionally, ' $A$ is $B$ or $A$ is not $B$ ' (any given thing either has or lacks any given property), or in the propositional calculus (where ' $p$ ' stands for a proposition) " $p$ or not $p$. .").

87. See Treas. Reg. $\S 301.7701-2(b)(1)$ (as amended in 2007) (defining "corporation" for tax purposes)

88. See Borden, supra note 5, at 994-98 (discussing pure service arrangements and the sourceof-activity test used to define tax partnership).

89. See Treas. Reg. § 301.7701-1(a)(2) (as amended in 2006) (discussing arrangements that "give rise to entities for federal tax purposes"). 
arrangements would be to litigate the question and rely upon the court's holding. The uncertainty prior to such a determination raises planning difficulties for taxpayers, who cannot know ex ante the classification of their arrangements. ${ }^{90}$

Members of an arrangement, the classification of which is uncertain without a court's holding, may prefer to be exempt from subchapter K. ${ }^{91}$ Such members would realize that if the arrangement is not a tax partnership, they will not be subject to subchapter $\mathrm{K}$ or other provisions of the Code; if the arrangement is a tax partnership, they will be subject to subchapter K, unless they make a valid section 761 election. ${ }^{92}$ They may also understand that if they make a valid section 761 election, they will be exempt from subchapter $\mathrm{K}$, even if the arrangement is a tax partnership. ${ }^{33}$ If the members of an arrangement are uncertain about whether the arrangement is a tax partnership and wish to be exempt from subchapter K, they will make a protective section 761 election. $^{94}$

To analyze how a protective section 761 election affects the classification of a qualified tax partnership, consider how the issue would arise. An arrangement makes a protective section 761 election if the members are uncertain about whether the arrangement is disregarded or is a tax partnership. The arrangement makes a protective, as opposed to actual, election because it provides some support for disregarded

90. The uncertainty of an arrangement's classification does not make the line between disregarded arrangements and tax partnerships any less definite. All arrangements are either tax partnerships or not tax partnerships. The uncertainty of an arrangement's classification relates to the position of the line between disregarded arrangements and tax partnerships, not the definiteness of the line. In other words, the line definitely exists, but its location is uncertain.

91. See infra Part IV (discussing the qualified tax partnership aggregate-plus tax regime and the tax consequences of qualified tax partnership classification).

92. For example, a taxpayer acquiring an interest in co-owned rental property may prefer that the interest not be a tax partnership so the acquisition may qualify for section 1031 nonrecognition. See I.R.C. $\S 1031(a)(2)(D)$ (2000) (excluding interests in a qualified tax partnership from the scope of section 1031).

93. See infra Part IV.

94. Some practitioners are concerned that making a protective section 761 election may cause an arrangement to become a tax partnership. An arrangement may make a section 761 election by filing a partnership tax return or it may make a deemed election in an un-filed document. See Treas. Reg. $\S 1.761-2$ (b)(2)(i) (as amended in 1995) (regarding actual elections); Id. $\S 1.761-2(\mathrm{~b})(2)(\mathrm{ii})$ (regarding deemed elections). Filing a tax return is an indicium of intent to be a partnership, but it is not dispositive. See Madison Gas \& Elec. Co. v. Comm'r, 72 T.C. 521, 558 (1979), aff'd, 633 F.2d 512 (7th Cir. 1980) ("[T]he fact that the partners elected under section 761(a) not to be subject to the provisions of subchapter $\mathrm{K}$ is not an admission that the arrangement is a [tax] partnership."); Greenspon v. Comm'r, 229 F.2d 947, 951 (8th Cir. 1956) (holding that an arrangement that filed a partnership tax return was not a tax partnership); Luna v. Comm'r, 42 T.C. 1067, 1077-78 (1964) (including whether a partnership files a tax return as a factor courts consider in determining whether an arrangement is a tax partnership). If the arrangement has no other indicia of tax partnership, filing a protective section 761 should not cause the arrangement to be a tax partnership. To avoid this possibility, most such arrangements make a deemed election. 
arrangement classification. If the IRS challenged that position, the members and IRS could litigate the issue. If the conclusion of that litigation were that the arrangement is a tax partnership, the taxpayers would invoke the protective section 761 election and argue that the arrangement is a qualified tax partnership. If the conclusion of the litigation were that the arrangement is a disregarded arrangement, the issue of the protective section 761 election and whether the arrangement is a disregarded arrangement would never arise. Even though this is the only acceptable conclusion, the issue is often confused.

Because the proper classification of non-corporate arrangements is not always clear and because some arrangements that are not tax partnerships make protective section 761 elections, some may perceive the group of qualified tax partnerships as spanning the groups of tax partnerships and disregarded arrangements. Under that interpretation, some qualified tax partnerships would be within a subgroup of disregarded arrangements, but not within the tax partnerships subgroup. The following Venn diagram illustrates that incorrect perception.

\section{Incorrect Perception of Protective Section 761 Elections}

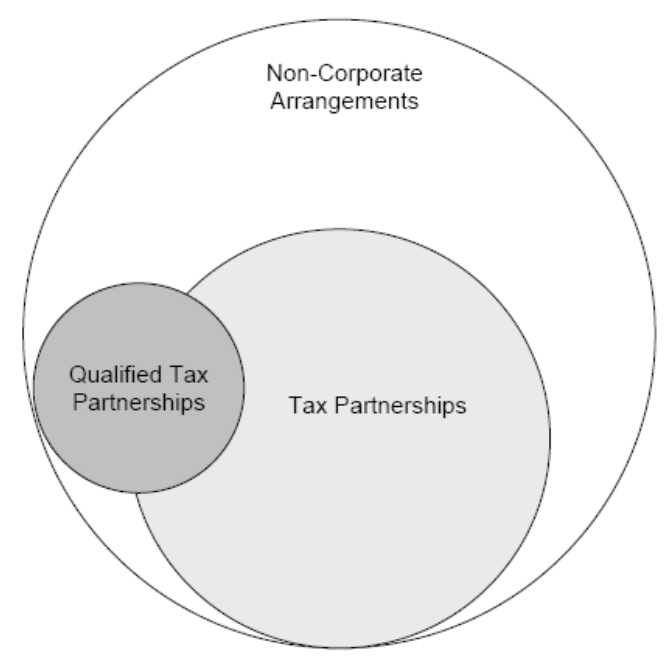

The concept this diagram illustrates is inconsistent with the definitional construct of non-corporate arrangements. Recall that the classification system first considers whether a non-corporate arrangement is a tax partnership or a disregarded arrangement. If the arrangement is a tax partnership and satisfies the section 761 requirements, it may elect to be a qualified tax partnership. If an arrangement is not a tax partnership, it has no need to make the election 
because it is not subject to the rules from which it would be electing exemption. Finally, section 761 is a part of subchapter $\mathrm{K},{ }^{95}$ and because subchapter $\mathrm{K}$ only applies to tax partnerships, a disregarded arrangement could not make an effective section 761 election. ${ }^{96}$ Thus, a protective election does not alter the groupings of non-corporate arrangements.

\section{QUALIFIED TAX PARTNERSHIP AGgREGATE-Plus TAXATION}

The definitional grouping of non-corporate arrangements helps identify the type of arrangements that are qualified tax partnerships (in other words, those non-corporate arrangements that are tax partnerships and qualify to make a section 761 election). In considering qualified tax partnership aggregate-plus taxation, recall the tax regime groupings discussed in Part II above. Qualified tax partnerships are subject to aggregate taxation plus some non-aggregate tax rules, but not as many non-aggregate tax rules as tax partnerships are subject to. Tax law creates the aggregate-plus tax regime by exempting qualified tax partnerships from subchapter $\mathrm{K}$ and some other Code provisions that generally apply to tax partnerships.

\section{A. Exemption from Subchapter $K$}

Qualified tax partnerships are exempt from all or a part of subchapter $\mathrm{K}^{97}$ Many of the provisions of subchapter $\mathrm{K}$ provide taxpayers favorable tax treatment. ${ }^{98}$ Perhaps most significantly, subchapter $\mathrm{K}$ has relatively lenient allocation rules. ${ }^{99}$ Members of a disregarded arrangement, on the other hand, must allocate items of income and loss

95. Section 761 is in part III of subchapter K of the Code.

96. See Madison Gas \& Elec. Co., 72 T.C. at 563 ("If distribution in kind of jointly produced property is enough to avoid partnership status, we do not see how such distribution could be used as a test for allowing an election to be excluded from the partnership provisions of subchapter K."). This statement by the Tax Court indicates that it understands qualified tax partnerships to be a subset of tax partnerships, i.e., tests for qualified tax partnerships would not apply in determining whether an arrangement is a tax partnership.

97. See I.R.C. § 761(a) (2000); McMahon, supra note 32, at 21 (“Any oil and gas joint operating agreement that is classified as a partnership rather than as an association under the rules discussed in the preceding section may elect to be excluded from all or part of the application of subchapter K. In practice, total exclusions are the rule."). $\mathrm{K})$.

98. See Larason, supra note 32 , at 30-31 (identifying tax advantages provided by subchapter

99. See I.R.C. $\S 704$ (b) (2000) (allowing partners to determine the allocation of partnership income, gain, loss, deduction, and credit by agreement, subject to the substantial economic effect test). 
to members of the arrangement based on their interests in the arrangement. ${ }^{100}$

Also, the formation and dissolution of a partnership will generally be tax free. ${ }^{101}$ The formation of a disregarded arrangement may, however, be a taxable event. ${ }^{102}$ For example, if parties contribute non-like-kind property to an arrangement (they exchange interests in individuallyowned property), the formation of the arrangement may be a taxable event for each member. ${ }^{103}$ Also consider a property owner who is in need of cash to pay property tax. The property owner can contribute the property to a partnership newly formed with someone willing to contribute cash sufficient to cover the taxes. The formation of that partnership will be tax free. ${ }^{104}$ If the property owner instead transferred an interest in the property to the person in exchange for the person paying the property tax and afterwards the parties held the property as tenants in common, the formation of the arrangement would be taxable. ${ }^{105}$ Similarly, the dissolution of a disregarded arrangement may not be tax free. For example, assume co-owners of multiple pieces of property decide to partition them, with each co-owner taking title to one of the properties. If any of the co-owners take one of the properties to hold primarily for sale, the dissolution could be taxable to such person. ${ }^{106}$

100. See Borden, supra note 5, at 951-56 (comparing the partnership allocation rules to the assignment-of-income doctrine).

101. See I.R.C. $\S 721$ (a) (2000) ("No gain or loss shall be recognized to a partnership or to any of its partners in the case of a contribution of property to the partnership in exchange for an interest in the partnership."); id. $\S 731$ (a)(1) ("In the case of a distribution by a partnership to a partner[,] gain shall not be recognized to such partner, except to the extent that any money distributed exceeds the adjusted basis of such partner's interest in the partnership immediately before the distribution ...."); id. $\S 731$ (a)(2) ("In the case of a distribution by a partnership to a partner ... [,] loss shall be not be recognized to such partner, except that upon a distribution in liquidation of a partner's interest ....”). The admission of a partner in exchange for services may, however, be a taxable event. See Treas. Reg. $\S 1.721-1(b)(2)$ (as amended in 1996) ("To the extent that the value of such interest is: (i) [c]ompensation for services rendered to the partnership, it is a guaranteed payment for services under section 707(c) ....").

102. See McMahon, supra note 32, at 35-36 (providing that section 721 would not apply to the formation of a qualified tax partnership, but the formation of oil and gas joint operating agreements may nonetheless be tax free under the pool of capital doctrine).

103. See Borden, supra note 5, at 960-61. If the parties exchange interests in like-kind property and both parties hold the property for productive use in a trade or business or for investment, both before and after the exchange, the formation of the arrangement should be tax free under section 1031 .

104. See I.R.C. $§ 721$ (a) (2000) ("No gain or loss shall be recognized to a partnership or to any of its partners in the case of a contribution of property to the partnership in exchange for an interest in the partnership.").

105. See id. $\S 1001$ (a) (providing that gain or loss shall be recognized on the sale or other disposition of property).

106. Section 1031 could apply to the dissolution of many co-ownership arrangements that are disregarded for tax purposes if the parties satisfy the section 1031 requirements, including the 
Perhaps an arrangement could elect out of all provisions of subchapter $\mathrm{K}$ other than the formation provisions and the dissolution provisions to avoid recognition of gain or loss on formation or dissolution. ${ }^{107}$

Members of an arrangement who intend to allocate tax items in proportion to their respective ownership interests in the arrangement's property, will not otherwise receive unfavorable tax treatment, and will not benefit from subchapter K, may prefer to elect out. A valid election will allow them to avoid the reporting requirements subchapter $\mathrm{K}$ imposes and to avoid the TEFRA audit rules. ${ }^{108}$ The TEFRA audit rules may cause a tax year to remain open longer with respect to partnership items than it would with respect to the members' individual tax items. ${ }^{109}$ Thus, taxpayers may generally prefer to avoid the TEFRA rules.

These simple examples demonstrate that the members of some arrangements would prefer to be subject to subchapter $\mathrm{K}$ while others would not. The section 761 elections allow eligible tax partnerships to decide whether to be subject to subchapter $\mathrm{K}$ or avoid it. While this may simplify tax administration (a non-electing tax partnership will not be a qualified tax partnership; a tax partnership that makes a valid section 761 election will be a qualified tax partnership), ${ }^{110}$ it may not produce

holding and use requirements. See id. $\S 1031(a)(1)$ (requiring that an exchanger hold relinquished property for productive use in a trade or business or for investment and acquire replacement property to be held for productive use in a trade or business or for investment); Rev. Rul. 73-476, 1973-2 C.B. 300 (ruling that the partition of three separate parcels of real property among tenants in common qualifies for section 1031 nonrecognition); Rev. Rul. 57-244, 1957-1 C.B. 247 (ruling that parties who exchanged formerly co-owned property qualified for section 1031 nonrecognition). If the partition is of a single piece of property, then the partition may not be a sale or exchange. See I.R.S. Priv. Ltr. Rul. 9633028 (May 20, 1996) (ruling privately that a partition of a single piece of property is not "a sale or exchange on which a gain or loss is realized . . .."); see Borden, supra note 5, at 995 (demonstrating that if an arrangement held property primarily for sale, it probably would be a tax partnership). Subchapter K would apply to such an arrangement. If the co-ownership held the property for investment or leased it, the co-ownership arrangement could be disregarded. See Gilford v. Comm'r, 201 F.2d 735, 736 (2d Cir. 1953) (declaring that services required to maintain property in rental condition are not sufficient for establishing tax partnership).

107. Apparently no authority exists on this point other than section 761. Unfortunately, section 761 does not indicate out of which provisions of subchapter $\mathrm{K}$ an arrangement can elect and which it can follow. Perhaps something analogous to the interdependence test would apply to provisions within subchapter K. See infra text accompanying notes 113-15 (discussing the interdependence test). If that test applies, those provisions that do not require the partnership to compute income or file a tax return could apply even though the arrangement makes a section 761 election. A partnership generally does not recognize gain or loss on the contribution or distribution of property, so the partnership generally should not have to compute partnership income or file a tax return if sections 721 and 731 apply to the partnership. See supra text accompanying note 101. If a contribution or distribution did require the partnership to compute taxable income or file a return, the nonrecognition provisions should not apply to a qualified tax partnership.

108. Tax Equity and Fiscal Responsibility Act of 1982, Pub. L. No. 97-248, § 402(a), 96 Stat. 648, 648-67 (codified at I.R.C. $\S \S 6221-6232$ (2000)).

109. I.R.C. $\S 6229$ (a) (West 2002).

110. But see Steven A. Dean, Attractive Complexity: Tax Deregulation, the Check-the-Box 
equitable results (two similarly situated arrangements would be subject to different tax treatment). ${ }^{111}$

\section{B. The Interdependence Test}

Even if a qualified tax partnership is exempt from all of subchapter $\mathrm{K}$, other sections of the Code may recognize the qualified tax partnership and treat it as any other tax partnership. ${ }^{112}$ Predicting which other Code sections will recognize qualified tax partnerships is difficult. The IRS has suggested that an interdependence test determines whether a particular Code section will disregard qualified tax partnerships. ${ }^{113}$ As stated by the IRS, the interdependence test provides that "if a particular section of the Code is 'interdependent' with section 761(a), the [qualified tax] partnership should not be treated as a partnership for purposes of such section." "The question in each instance is whether the limitation or rule outside of subchapter $\mathrm{K}$ can be applied without doing violence to the concept of electing out of subchapter $\mathrm{K}$ and computing income and deductions at the partner level." ${ }^{115}$ Thus, the application of the

Election, and the Future of Tax Simplification, 34 HofSTRA L. REV. 405, 430-32 (2005) (arguing that elective tax rules create complexity because they require taxpayers to analyze the different possible alternatives).

111. See Borden, supra note 5, at 969-70 (arguing that partnership taxation should not be elective; instead, the application of the partnership tax rules should depend upon a policy-supported definition of tax partnership).

112. See Bryant v. Comm'r, 46 T.C. 848, 864 (1966) ("The election under section 761(a) does not operate to change the nature of the entity. A partnership remains a partnership; the exclusion simply prevents the application of subchapter $\mathrm{K}$. The partnership remains intact and other sections of the Code are applicable as if no exclusion existed."), aff'd, 399 F.2d 800 (5th Cir. 1968); McMahon, supra note 32, at 30 ("But an election under section 761(a) does not cause the organization to cease to be a partnership for all purposes under the Code.").

113. The Tax Court is the first legal authority to introduce the concept of interdependence in the section 761 context. The court stated, "[i]n our opinion sections 761(a) and 48(c)(2)(D) are not interdependent. When Congress has subtitlized, subchapterized, and sectionized its treatment of a many threaded statutory pattern like the complex Internal Revenue Code, its clear words seem to us a safe guide to meaning." Bryant, 46 T.C. at 864 .

114. I.R.S. Gen. Couns. Mem. 36,982 (Jan. 13, 1977).

115. I.R.S. Gen Couns. Mem. 39,043 (Oct. 5, 1983). The IRS's position appears to contradict the plain language of the Tax Court in Bryant, which provided:

[T] he Commissioner is empowered by section 761(a) to exclude a partnership 'from the application of all or a part of this subchapter.' Such exclusion from partnership treatment is expressly limited by the plain language of the statute. The Commissioner does not have the authority to redefine what a partnership is; he is only empowered to exclude partners from being treated as such under one specific subchapter.

Bryant, 46 T.C. at 864 . As the court continued, however, it indicated that the purpose of the statutory language is important: "If we were to accept the argument advanced by petitioners, we would necessarily extend the Commissioner's power of exclusion to other sections of the Code outside subchapter $\mathrm{K}$. This we are unwilling to do because it would not be within the spirit or intendment of the statute as enacted by Congress." Id. (emphasis added). The IRS considered the 
interdependence test turns on whether a Code section is interdependent with section 761(a).

\section{Interdependent Code Sections}

Interdependent Code sections disregard qualified tax partnerships. ${ }^{116}$ A Code section is interdependent with section 761(a) if its application requires qualified tax partnerships to compute partnership income or file a partnership tax return. ${ }^{117}$ Under the interdependence test, any provision of the Code that requires an election to be made by filing a return (other than for the purpose of making an election under section 761$)^{118}$ would disregard qualified tax partnerships. ${ }^{119}$ Thus, section 453, which applies the installment method to dispositions by taxpayers who do not elect out of such treatment, would disregard qualified tax partnerships. Each member of a qualified tax partnership could individually elect out of section 453. ${ }^{120}$ For example, assume Mark and Julie are the only members of a qualified tax partnership that owns Knopp Farm. ${ }^{121}$ Mark and Julie agree to sell Knopp Farm to Raven. Raven will pay thirty percent of the purchase price at closing and issue a note to Mark and

spirit and intendment of the statute in defining the interdependence test-it suggests that provisions outside of subchapter K should not apply if they will do violence to the intendment of section 761 election.

116. A Code section that does not apply to qualified tax partnerships in effect disregards them. Because disregarding entities is a concept known in tax law, see Treas. Reg. $§ 301.7701-1(a)(4)$ (as amended in 1996) ("[C]ertain organizations that have a single owner can choose to be recognized or disregarded as entities separate from their owners."), this Article refers to Code sections that do not apply to qualified tax partnerships disregarding such arrangements. See also Noah S. Baer, Oil and Gas Transactions, 605 TAX MGM'T PORTFOLIOS A-61 ("If ['sections cannot apply without doing violence to the concept of the section 761 election'], the sections are 'interdependent' and the election must apply to the non-subchapter K section.") (footnotes omitted).

117. See I.R.S. Gen. Couns. Mem. 36,982 (Jan. 13, 1977).

118. See supra note 59 and accompanying text.

119. See I.R.S. Gen. Couns. Mem. 36,982 (Jan. 13, 1977) (providing that section 616(b) of the Internal Revenue Code of 1954 is interdependent with section 761(a) because that section required the qualified tax partnership to file a return to make an election, and therefore section 616(b) did not apply to the qualified tax partnership).

120. See I.R.C. $\S 453(d)(2)$ (2000) (requiring a taxpayer to make the election on or before the due date of the taxpayer's return of the tax imposed for the taxable year of the disposition and referring to the regulations for the manner in which the election is to be made); Treas. Reg. $\S$ 15a.453-1(d)(3)(i) (as amended in 1994) (providing that a taxpayer makes the election out of the installment sale method on the appropriate forms for the taxpayer's return or by reporting the full face amount of an installment note as the amount realized in the year of disposition).

121. This example assumes that the arrangement is a tax partnership that may make a valid section 761 election. A mere co-ownership would not, however, be a tax partnership. See Treas. Reg. $\S 301.7701-1(a)(2)$ (as amended in 1996). Thus, for the arrangement to be a tax partnership and be eligible to make a valid section 761 election either Mark or Julie must perform some nonbusiness activities with respect to the property. See infra Part IV.B.3 and accompanying notes. 
Julie payable over the next ten years. Assume the sale qualifies for the installment method.

Mark and Julie have different tax situations, so they prefer different tax treatment on the sale of Knopp Farm. Mark has a significant amount of loss in the current year that will offset any gain that he would realize without the installment method. Julie wants to recognize gain on payment of the note under the installment method. Because the qualified tax partnership would have to file a tax return to make the election, ${ }^{122}$ section 453 should disregard the return and Mark should be able to elect out of section 453. Julie's choice to recognize gain under the installment method should affect Mark's election.

This example appears to be the proper application of the interdependence test to an interdependent section of the Code. Any other section that requires an election to be made by filing a return would also be interdependent with section 761 and disregard qualified tax partnerships. ${ }^{123}$ In each case, applying the election at the partnership level would do violence to the concept of the exemption from subchapter $\mathrm{K} .{ }^{124}$ Thus, the interdependence test would require such other Code sections to disregard qualified tax partnerships. Similarly, a section that requires an arrangement to compute taxable income should disregard qualified tax partnerships.

\section{Non-Interdependent Code Sections}

A Code section is non-interdependent if it can apply without the partnership computing income or filing a return. ${ }^{125}$ The negative implication of the interdependence test appears to be that noninterdependent Code sections must recognize qualified tax partnerships. $^{126}$ Case law and IRS rulings reveal, however, that while

122. See Treas. Reg. § 15a.453-1(d)(3)(i) (as amended in 1994).

123. See, e.g., I.R.C. $§ 168(\mathrm{~b})(5)$ (2000) (allowing certain taxpayers to elect to use the $150 \%$ declining balance or the straight line method); id. $\S 168(\mathrm{~g})(7)$ (allowing a taxpayer to use the alternative depreciation system); see also id. $\S 1033(\mathrm{a})(2)(\mathrm{A})$ (allowing taxpayers who replace involuntarily converted property within the allowed time period to elect to defer gain recognition on such conversion); Treas. Reg. § 1.1033(a)-2(c)(2) (as amended in 1981) (providing that taxpayers make the election under section 1033 by including only the portion of undeferred gain in gross income for the year); Morburger v. United States, 303 F. Supp. 42, 44 (W.D. Ky. 1969) (holding that a member of a qualified tax partnership may individually elect to deduct his share of the arrangement's intangible drilling costs).

124. See supra text accompanying note 115 .

125. This is the negative proposition of the interdependence test. See supra text accompanying note 117.

126. See supra note 115 (indicating that provisions outside of subchapter K apply to qualified 
some non-interdependent Code sections do recognize qualified tax partnerships, others may not. Code sections that grant limited-dollar credits may not require the computation of partnership income or the filing of a partnership return to determine the amount of the limit. ${ }^{127}$ Such Code sections would recognize qualified tax partnerships and apply the dollar limit at the qualified tax partnership level. The qualified tax partnership would then allocate the credit to its members. ${ }^{128}$

In Madison Gas \& Electric Co., the Seventh Circuit held that a coowned joint-production arrangement was a tax partnership and required the arrangement's members to capitalize pre-operation expenditures instead of allowing them to take a deduction for the cost of expansion. ${ }^{129}$ That same arrangement should be able to make an election under section 761(a)(2) to be a qualified tax partnership. ${ }^{130}$ Section 195, requiring taxpayers to capitalize pre-operation expenditures, can apply even if the arrangement does not file a tax return or compute income at the entity level. Therefore, section 195 is not interdependent with section 761, and the interdependence test does not require section 195 to disregard qualified tax partnerships. Furthermore, applying section 195 to a qualified tax partnership would not do violence to the concept of electing out of subchapter K. Thus, section 195 should always recognize qualified tax partnerships and treat pre-operation as start-up expenditures, not expansion costs. ${ }^{131}$

tax partnerships); Borden, supra note 5, at 949, n.112 ("If, however, the other section is not interdependent with section 761(a), the qualified partnership will be treated as a partnership for purposes of such other section .... But see I.R.C. § 1031(a)(2)(D) (2000) (disregarding a qualified tax partnership for section 1031 purposes)."); Borden, supra note 32, at 57 ("Several sections of the Code are not interdependent with $\S 761$ (a) and therefore will treat qualified partnerships as partnerships for purposes of the other sections.").

127. Rev. Rul. 65-118, 1965-1 C.B. 30 (ruling that the former section 48(c)(2)(A) dollar limitation for used property credit applied at the partnership level).

128. Id. The members of a qualified tax partnership would, of course, prefer that the Code section granting the credit disregard the qualified tax partnership so the members could individually take the full amount of the credit, instead of dividing it among themselves.

129. See Madison Gas \& Elec. Co. v. Comm'r, 633 F.2d 512, 517 (7th Cir. 1980) ("We hold therefore that MGE's joint venture with WPS and WPL constitutes a partnership within the meaning of Sections 7701(a)(2) and 761(a) of the Code."). The taxpayers in Madison Gas \& Electric Co. made a section 761(a)(2) election. Id. at $516 \mathrm{n} .2$. On appeal the taxpayer argued that the Tax Court's holding was inconsistent with the purpose of section 761(a). Id. Because the taxpayer failed to raise that issue in the Tax Court, the Seventh Circuit did not consider whether a valid section 761 election would have affected its decision. Id. The court did note, however, that section 7701(a)(2) applies for purposes of all sections of the Code and section 761 provides for an election out of only subchapter K. $I d$.

130. See Rev. Rul. 68-344, 1968-1 C.B. 569 ("[T]he language of the section contemplates that eligibility to make the election may be present ... so long as they otherwise meet the requirements of the regulations.").

131. Even though the court in Madison Gas \& Electric Co. did not consider the possible result of an arrangement that makes a valid section 761 election, it indicated that the section 7701(a)(2) 
Other Code sections would also be non-interdependent with section 761. For example, the sections governing the character of gain recognized on the disposition of a partnership interest can be applied without computing income at the partnership level and without requiring the arrangement to file a tax return. ${ }^{132}$ Nonetheless, the character of gain recognized on the disposition of qualified tax partnership property should depend upon the member's holding intent, not the arrangement's. ${ }^{133}$ Also, the definition of self-employment income in section 1402 does not require qualified tax partnerships to compute income at the arrangement level or file a partnership tax return. ${ }^{134}$ Section 1402 thus appears to be non-interdependent and could apply without doing violence to the section 761 election. Although these and other Code sections are not interdependent with section 761(a), policy does not always support recognition of qualified tax partnerships. ${ }^{135}$ Therefore, the negative implication of the interdependence test (that all non-interdependent Code sections must recognize qualified tax partnerships) may not be correct.

\section{Specific Overrides}

The interdependence test would not apply to any Code section that specifically overrides the test. For example, section 1031(a)(2)(D), which disqualifies interests in partnerships from section 1031 nonrecognition, ${ }^{136}$ does not appear to be interdependent with section 761 . A qualified tax partnership does not have to compute income or file a tax

definition would apply for purposes of analyzing the proper treatment of pre-operation costs. See supra note 129 (noting that section 7701(a)(2) applies for purposes of all Code sections). Determining whether an expenditure is deductible or must be capitalized does not require the arrangement to compute taxable income or file a tax return. Therefore, as the text states, the capitalization rules are not interdependent with section 761. Thus, the court's decision should have been the same, even if it had considered the issue in the context of a valid section 761 election.

132. See, e.g., Gilford v. Comm'r, 201 F.2d 735, 736 (2d Cir. 1953) (holding that the loss from the sale of rental real property held by tenants in common for use in a trade or business was ordinary under section 1231, but if relevant Code sections had recognized the partnership, the sale would have been of a partnership interest and the loss may have been a capital loss that the taxpayer could have carried forward to a subsequent year). Although this case did not involve a qualified tax partnership (the court held that the arrangement was not a tax partnership), the same result should obtain if the partnership at issue had been a qualified tax partnership.

133. See McMahon, supra note 32 , at 33 ("Clearly, if an interest in an electing out partnership is sold, the transaction should be treated as a sale of the underlying property, not a partnership interest."); infra text accompanying note 202 (discussing the result when the character of gain or loss is determined at the arrangement level).

134. See Cokes v. Comm'r, 91 T.C. 222, 232 (1988) (recognizing a qualified tax partnership for purposes of applying the section 1402 definition of self-employment income).

135. See supra Part IV.B.1.

136. I.R.C. $§ 1031(a)(2)(D)(2000)$. 
return for its members to have interests in it. ${ }^{137}$ Nonetheless, Congress treats section 1031 as interdependent with section 761(a) by disregarding qualified tax partnerships and treating their members as directly owning the assets of the qualified tax partnership. ${ }^{138}$ Therefore, Congress specifically overrode the interdependence test in this situation.

\section{Qualified Tax Partnership Hybridism}

Because of interdependence, a qualified tax partnership is a hybrid of a tax partnership and a disregarded arrangement. If a qualified tax partnership is exempt from all of the provisions in subchapter $K$, then it looks more like a disregarded arrangement than a tax partnership. Nonetheless, some non-interdependent Code sections continue to apply to qualified tax partnerships. ${ }^{139}$ In this respect, the hybridism of qualified tax partnerships resembles the hybridism of $\mathrm{S}$ corporations. $\mathrm{S}$ corporations are exempt from some entity tax provisions: for example, income, gain, loss, deductions, and credits flow through to shareholders. ${ }^{140}$ Nonetheless, $\mathrm{S}$ corporations remain subject to many entity tax provisions. ${ }^{141}$ Thus, $\mathrm{S}$ corporations are a hybrid of $\mathrm{C}$ corporations and tax partnerships. Similarly, qualified tax partnerships are exempt from many of the partnership tax rules, but remain subject to at least some non-interdependent Code sections. Thus, qualified tax partnerships are a hybrid of tax partnerships and disregarded multiplemember arrangements. The following Venn diagram illustrates the hybridism of qualified tax partnerships.

137. See id. § 761(a) (definition of partnership lacks any requirement of income computation or a filed tax return).

138. Congress added the provision as part of the Omnibus Budget Reconciliation Act of 1990, Pub. L. No. 101-508, § 11703(d)(1), 104 Stat. 1388, 1388-517.

139. See supra text accompanying notes $125-35$.

140. See I.R.C. § 1363(a) (2000) (“" [A]n S corporation shall not be subject to the taxes imposed by this chapter."); id. § 1366(a)(1)(A)-(B) (requiring S corporation shareholders to take into account that corporation's "items of income (including tax-exempt income), loss, deduction, or credit the separate treatment of which could affect the liability for tax of any shareholder, and... nonseparately computed income or loss").

141. See id. § 1371(a) ("Except as otherwise provided in this title, and except to the extent inconsistent with this subchapter, subchapter $\mathrm{C}$ shall apply to an $\mathrm{S}$ corporation and its shareholders."). 


\section{Current Tax Treatment of Non-Corporate Arrangements}

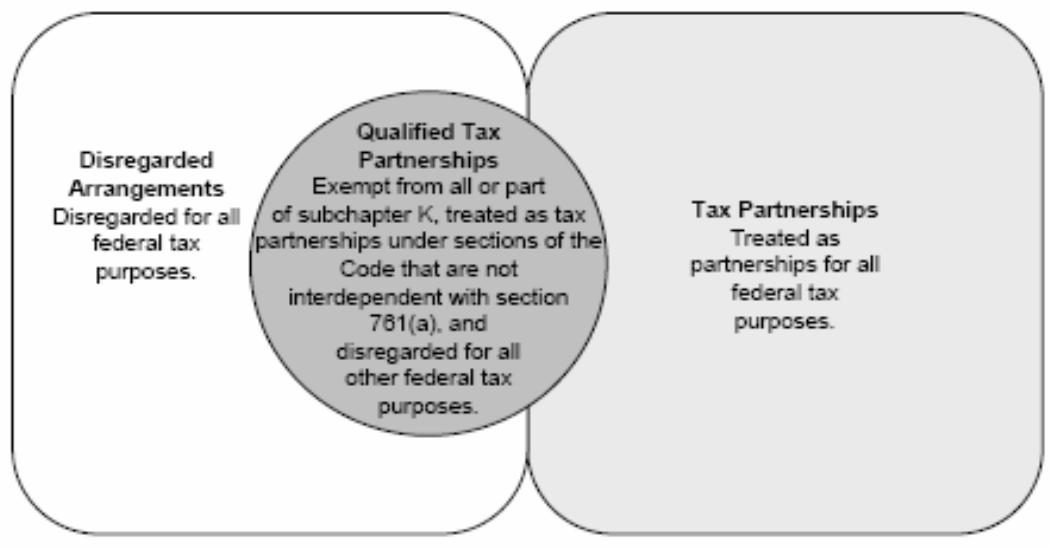

The definition of qualified tax partnership determines which tax partnerships may be exempt from subchapter $\mathrm{K}$ and disregarded in other provisions of the Code. That classification may have significant tax consequences. $^{142}$ Thus, it is an important definition. Furthermore, because the effect of the definition of qualified tax partnership is to exempt tax partnerships from subchapter $\mathrm{K}$ and other provisions of the Code, the definition should reflect policy considerations that justify such exemption.

\section{Policy Analysis of Qualified Tax Partnerships}

Tax policy justifies the existence of qualified tax partnerships only if they are sufficiently different from both tax partnerships and disregarded arrangements to warrant a special regime. ${ }^{143}$ If tax partnerships are not sufficiently different from other arrangements, their existence adds complexity to tax law and may result in similarly situated taxpayers being treated differently for tax purposes. Thus, the policy analysis of qualified tax partnerships compares them to tax partnerships and then compares them to disregarded arrangements. If they are not sufficiently

142. See, e.g., Madison Gas \& Elec. Co. v. Comm'r, 633 F.2d 512, 514 (7th Cir. 1980) (noting the amount of potential deduction at issue was $\$ 33,418.45$ and $\$ 114,434.27$ for 1969 and 1970 respectively).

143. See Borden, supra note 5, at 1002-06 (discussing the application of horizontal equity). 
different from both types of arrangements, they should not exist. Instead, they should be subsumed by the type of arrangement to which they are most similar.

\section{A. Comparison of Tax Partnerships and Qualified Tax Partnerships}

The IRS has stated that the interdependence test prevents certain Code sections from doing violence to the purpose of section $761 .^{144}$ That reasoning is consistent with the stated purpose of section $761:{ }^{145}$ to alleviate the hardship caused by Bentex Oil Corp. v. Commissioner. ${ }^{146}$ In Bentex Oil, the Tax Court held that a co-owned joint-production arrangement was a tax partnership, which subjected the arrangement to subchapter $\mathrm{K} .{ }^{147}$ Subchapter $\mathrm{K}$ requires tax partnerships to compute taxable income. ${ }^{148}$ Co-owned joint-production arrangements cannot, however, easily compute taxable income. ${ }^{149}$ The co-owners, not the arrangement, own the product of the arrangement. ${ }^{150}$ Because the arrangement does not own the product, the arrangement never has an accession to wealth that it clearly realizes and over which it has complete dominion. ${ }^{151}$ Thus, the arrangement does not have gross income and cannot compute taxable income. ${ }^{152}$ Instead, the co-owners recognize income individually when they separately sell the product. The following diagram illustrates the Bentex Oil hardship.

\footnotetext{
144. Supra note 115.

145. See Madison Gas \& Elec. Co., 633 F.2d at 515-16 ("Section [761(a)] has generally been interpreted, in the absence of any legislative history, as approving the Bentex decision while providing relief from certain resulting hardships .... This interpretation is surely correct...." (citations omitted)).

146. 20 T.C. 565 (1953).

147. Id. at 571 .

148. I.R.C. § 703(a) (2000).

149. See Borden, supra note 5, at 1019-23 (describing the steps necessary for such a calculation).

150. Borden, supra note 5, at 1022 .

151. See Comm'r v. Glenshaw Glass Co., 348 U.S. 426, 431 (1955) (defining gross income).

152. See I.R.C. $\S 63(a)$ (2000) (defining taxable income as gross income minus allowed deductions).
} 


\section{Bentex Oil Hardship}

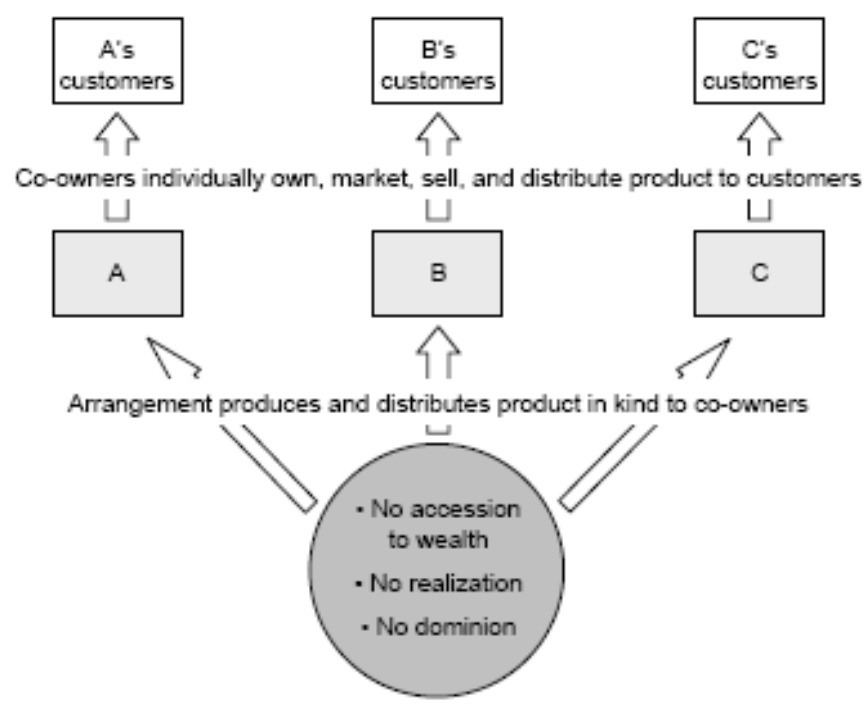

Because production qualified tax partnerships cannot compute gross income at the arrangement level, treating them as tax partnerships and requiring them to compute taxable income and file a partnership tax return would create a hardship. The inability to compute income at the partnership level is sufficient justification to treat qualified tax partnerships and other tax partnerships differently. ${ }^{153}$ Thus, the purpose of section 761 is to exclude qualified tax partnerships (arrangements which cannot compute taxable income) from subchapter $\mathrm{K}$. That exclusion alleviates the Bentex Oil hardship.

The interdependence test piggy-backs on the purpose of section 761 . As stated above, the interdependence test requires Code sections to disregard qualified tax partnerships if recognizing them would do violence to the purpose of section $761 .{ }^{154}$ In other words, if another section of the Code would require a qualified tax partnership to compute taxable income or file a partnership tax return, that other section of the

153. A principal policy justification for partnership taxation is that it alleviates administrative inconvenience. See Borden, supra note 5, at 943-44. If the arrangement has no partnership income, then the inconveniences partnership tax rules were enacted to alleviate do not exist. Furthermore, requiring such an arrangement to compute taxable income would add an inconvenience. Similarly, a co-ownership arrangement cannot compute taxable income because co-owners, not the arrangement, own the proceeds from the property. Therefore, requiring such an arrangement to compute taxable income would create, not alleviate, administrative inconvenience.

154. See supra notes $115-16$ and accompanying text. 
Code should disregard the qualified tax partnership. Thus, the interdependence test helps alleviate the Bentex Oil hardship and has policy support. Because the interdependence test has policy support, it justifies interdependent sections of the Code treating qualified tax partnerships differently from tax partnerships.

Instead of creating qualified tax partnerships, Congress could have narrowed the statutory definition of tax partnership to exclude arrangements that fall under the current definition of qualified tax partnership. If Congress had done that, non-corporate arrangements would consist of only tax partnerships and disregarded arrangements. Disregarded arrangements would include all arrangements that would otherwise be subject to the Bentex Oil hardship.

Congress did not, however, amend the statutory definition of tax partnership. Instead, it created qualified tax partnerships. If Congress based that decision on sound tax policy, the only explanation is that qualified tax partnerships are sufficiently different from disregarded arrangements to justify treating the two types of arrangements differently. The analysis thus compares qualified tax partnerships and disregarded arrangements to determine whether they are sufficiently different to warrant different tax treatment. If not, the existence of qualified tax partnerships is not justified.

\section{B. Comparison of Disregarded Arrangements and Qualified Tax Partnerships}

The Bentex hardship-alleviation purpose and the interdependence test only justify treating qualified tax partnerships and tax partnerships differently. They do not justify treating qualified tax partnerships and disregarded arrangements differently. ${ }^{155}$ Policy requires treating qualified tax partnerships and disregarded arrangements differently only if the difference between them justifies different tax treatment. ${ }^{156}$ Subchapter $\mathrm{K}$ and interdependent Code sections treat qualified tax partnerships and disregarded arrangements the same: they disregard both types of arrangements. Only non-interdependent Code sections treat qualified tax partnerships and disregarded arrangements differently. The

\footnotetext{
155. The court in Madison Gas \& Electric Co. used a pure legal analysis to hold that the arrangement was a tax partnership. It considered the definition of joint profit and, finding that the arrangement had a joint profit under the dictionary definition of profit, held that the arrangement was a tax partnership. See Madison Gas \& Elec. Co. v. Comm'r, 633 F.2d 512, 517 (7th Cir. 1980); Borden, supra note 5, at 990. The court did not consider whether tax policy supported its decision. If it had, it should have drawn a different conclusion. See Borden, supra note 5, at 1017-23.

156. See Borden, supra note 5, at 1002-06.
} 
analysis thus examines non-interdependent Code sections and considers whether tax policy supports their treating qualified tax partnerships and disregarded entities differently. If comparing qualified tax partnerships to disregarded arrangements reveals that different tax treatment is not justified, the courts in Bentex and Madison Gas \& Electric Co. created a definition of tax partnership that is too broad. ${ }^{157}$

The applicability of non-interdependent Code sections to qualified tax partnerships has not been at issue in many cases or rulings. Case law provides that certain investment credit Code sections and employment tax Code sections recognize qualified tax partnerships. ${ }^{158}$ Case law also implies that certain capitalization provisions would recognize qualified tax partnerships. ${ }^{159}$ Beyond that limited authority, nothing appears to specifically address other non-interdependent Code sections. Nonetheless, the interdependence test suggests that all noninterdependent Code sections recognize qualified tax partnerships. The following analysis considers Code sections directly addressed by case law and the gain/loss characterization Code sections. Considering these provisions illuminates weaknesses within the interdependence test. The analysis demonstrates that some non-interdependent provisions should recognize qualified tax partnerships, but others should not.

\section{Credit Limits}

The investment credit Code section that recognized qualified tax partnerships was property specific. The Code section allowed a tax credit of up to $\$ 50,000$ based upon the cost of a piece of property. ${ }^{160}$ Because the credit was property specific, allowing each member of a qualified tax partnership to take the full amount of the credit would have

157. Indeed, policy does not appear to support including co-owned joint-production arrangements as tax partnerships. See Borden, supra note 5, at 1028 (proposing a definition of tax partnership that would exclude investment qualified tax partnerships (by requiring that at least one member provide significant services) and production qualified tax partnerships (by requiring the members to have common gross income) from the definition of tax partnership).

158. See Bryant v. Comm'r, 399 F.2d 800, 806 (5th Cir. 1968) (holding that the $\$ 50,000$ credit limit in section 48(c)(2) of the 1954 Code applies at the partnership level of a qualified tax partnership); Cokes v. Comm'r, 91 T.C. 222, 229 (1988) (holding that section 1401 (imposing tax on self-employment income) recognizes qualified tax partnerships); Rev. Rul. 65-118, 1965-1 C.B. 30, 31 (ruling that the $\$ 50,000$ credit limit in section 48(c)(2)(D) of the 1954 Code applies at the level of a qualified tax partnership).

159. See Madison Gas \& Elec. Co., 633 F.2d at 517 (holding that a co-owned joint-production arrangement was a tax partnership for purposes of determining whether certain pre-operation costs were start-up expenditures or expansion costs, and whether the arrangement had made a valid section 761 election was irrelevant).

160. See I.R.C. $\S 48(a)(2)(D) ~(1963)$. 
multiplied the credit and neglected the purpose of the credit. It would have treated multiple owners of a single piece of property differently from a single owner of the same piece of property. That result would have been undesirable.

Other credit limits are not property specific and applying them at the partnership level of a qualified tax partnership would produce an unsupportable result. One example of an owner-specific credit limit is the low-income housing credit, which allows a credit based upon the qualified basis of each low-income building. ${ }^{161}$ If the building is owned by several members of a qualified tax partnership, each member will take a separate basis in its interest in the property. ${ }^{162}$ If the members do not acquire their interests simultaneously, or if some of them are subject to different depreciation rules, then their respective interests may have different bases. If that is the case, the interdependence test should not require the arrangement to determine the amount of the credit at the arrangement level. Instead, the members should individually determine the amount of credit available according to their respective interests and take the credit individually.

The members' proportionate shares of the property's aggregate basis may not equal their proportionate shares of the property's fair market value. Determining the credit amount at the arrangement level would produce a poor result if the arrangement allocated the credit based on the members' share of the value of the property. ${ }^{163}$ Thus, the low-income housing credit Code provisions should disregard qualified tax partnerships and apply the credit at the member level.

This discussion reveals that a general rule applicable to all tax credits is not workable. Some credit provisions should recognize qualified tax partnerships, others should not. Whether the particular provision should recognize qualified tax partnerships depends upon whether the amount of the credit derives from the property itself or from some other factor, such as the property's basis.

Tax policy appears to support the application of property-specific credits at the arrangement level of qualified tax partnerships. It does not, however, appear to support applying owner-specific credits at the

\footnotetext{
161. Id. § 42(a).

162. Assuming the qualified tax partnership's election was effective for all provisions in subchapter K, section 722 would not apply, and each partner would have an adjusted tax basis in the separately owned property interest under section 1011.

163. If the arrangement is not subject to the partnership allocation rules, the arrangement should allocate all tax items to its members based on their respective shares in the property. The bases the members had in their respective property interests should not affect their shares in the property. See Borden, supra note 5, at 951-56.
} 
qualified tax partnership level. Instead, policy suggests that ownerspecific credits should apply at the member level of qualified tax partnerships. Because property-specific provisions of the Code apply to the property, the existence or nonexistence of a qualified tax partnership should not affect the application of the provision. Thus, the application of the provision is not affected by an arrangement's tax classification.

\section{Self-Employment Tax Provisions}

Self-employed individuals must pay tax on self-employment income in an amount equal to the aggregate employment taxes an employee and employer pay. ${ }^{164}$ Self-employment income includes a partner's distributive share of partnership taxable income or loss from any trade or business. ${ }^{165}$ This rule appears to require the partnership to compute income at the partnership level. Nonetheless, the Tax Court held that income allocated to an individual member of a production qualified tax partnership is self-employment income, even though the member did not participate in the management of the arrangement. ${ }^{166}$ Income to members of investment clubs, however, is not self-employment income because such arrangements do not engage in business activity. ${ }^{167}$ Thus, the applicability of the definition of self-employment income to items of a qualified tax partnership appears to depend upon the type of qualified tax partnership. The income of a production qualified tax partnership would be self-employment income to its individual members. The income of an investment qualified tax partnership would not be selfemployment income to its individual members. Part of the reason for the distinction must be that investment qualified tax partnerships only conduct investment activities, which do not generate self-employment income. $^{168}$

Characterizing income from a production qualified tax partnership as self-employment income may be justified. ${ }^{169}$ Income allocated to an

164. See I.R.C. § 1401(a) (2000) (imposing a tax of $12.4 \%$ on self-employment income); id. § 1401(b) (imposing a tax of $2.9 \%$ on self-employment income).

165. See id. § 1402(a) (referring to section 702(a)(8) to define partnership taxable income). But see also id. $\S 1402(\mathrm{a})(13)$ (excluding from the definition of self-employment income a limited partner's distributive share of any item of gain or loss of a limited partnership other than guaranteed payments under section 707(c)).

166. Cokes v. Comm'r, 91 T.C. 222, 233-36 (1988).

167. Rev. Rul. 75-525, 1975-2 C.B. 350.

168. See supra note 67.

169. This statement assumes the arrangement has income. If the arrangement has income, perhaps it does not distribute product to its members in kind but sells it on behalf of the arrangement. If that were the case, the arrangement should not be a qualified tax partnership. See supra notes 73- 
individual member of a general partnership that conducts business activity would be self-employment income under the statutory definition. ${ }^{170}$ Disregarded entities may also engage in business activity. ${ }^{171}$ Income from a disregarded arrangement that engages in business activity should be self-employment income to the individual members of the arrangement under the statutory definition of selfemployment income. ${ }^{172}$ The classification of an arrangement as either a tax partnership or a disregarded arrangement does not affect whether income to the members of the arrangement is self-employment income. ${ }^{173}$ Instead, the nature of the arrangement's activities determines whether the income is self-employment income. ${ }^{174}$ Therefore, income from a qualified tax partnership should be self-employment income, if the income allocated to an individual member is income from the arrangement's business activity. Such activity-specific Code provisions do not depend upon the arrangement's classification.

\section{Pre-Operating Costs}

Requiring the members of a qualified tax partnership to capitalize pre-operating costs while allowing members of a disregarded arrangement to deduct the same costs is not equitable. The following

77 and accompanying text. The Tax Court appeared to rule on the self-employment income issue assuming the arrangement was a qualified tax partnership. See Cokes, 91 T.C. at 231. If the arrangement had not been a qualified tax partnership, it would have been a general partnership treated as a tax partnership for tax purposes, and the result would have been the same. $I d$.

170. See supra note 165 and accompanying text.

171. See, e.g., Pinchot v. Comm'r, 113 F.2d 718, 719 (2d Cir. 1940) ("What was done was more than the investment and re-investment of funds in real estate. It was the management of the real estate itself for profit.... It necessarily involved alterations and repairs commensurate with the value and number of buildings cared for and such transactions as were necessary constitute a recognized form of business. The management of real estate on such a scale for income producing purposes required regular and continuous activity of the kind which is commonly concerned with the employment of labor; the purchase of materials; the making of contracts; and many other things which come within the definition of business ...."); Gilford v. Comm'r, 201 F.2d 735, 736 (2d Cir. 1953) (declaring that holding business property as tenants in common is not sufficient for establishing a tax partnership and holding loss recognized by the members of the disregarded arrangement was loss from the sale of property used in a trade or business); Hazard v. Comm'r, 7 T.C. 372, 375-76 (1946) (holding that the property owner held rental property for use in a trade or business, even though business activity appears to have been minimal); Rev. Rul. 75-374, 1975-2 C.B. 261 (ruling that a co-ownership was not a tax partnership, because the member-hired manager who provided customary tenant services was not the members' agent).

172. See I.R.C. § 1402(a) (2000) ("The term 'net earnings from self employment' means the gross income derived by an individual from any trade or business carried on by such individual ....").

173. See id. (failing to distinguish between tax partnerships and disregarded entities in calculating net earnings from self-employment).

174. Id. 
comparison of two hypothetical arrangements illustrates the inequity. Alpha and Omega start Saturn Power Co., an electrical production qualified tax partnership. ${ }^{175}$ Alpha is a utility company with several other power plants. Because Saturn Power Co. is a qualified tax partnership, Alpha would be required to capitalize any pre-operating costs it incurs jointly to start Saturn Power Co. with Omega, such as employee training. ${ }^{176}$

Beta and Zeta acquire Zeus Apartments and hire Matt to manage Zeus Apartments. Before getting their first tenant, Beta and Zeta incur costs to train Matt. The Beta-Zeta arrangement is disregarded for tax purposes. ${ }^{177}$ Beta owns several apartment complexes. Beta's interest in Zeus Apartments is an expansion of Beta's apartment owning business, so Beta should be able to currently deduct pre-operating costs of Zeus Apartments. ${ }^{178}$ Tax policy analysis should turn on whether Saturn Power Co. and Zeus Apartments are sufficiently different to justify different tax treatment. ${ }^{179}$

175. The arrangement should be a tax partnership. Even though in Madison Gas \& Electric Company, the Seventh Circuit held that the arrangement was a tax partnership, it did not consider whether the arrangement qualified for the section 761 election. See Madison Gas \& Elec. Co. v. Comm'r, 633 F.2d 512, 516, n.2 (7th Cir. 1980) (stating that the availability of the section 761 election was not at issue in the case); Rev. Rul. 68-344, 1968-1 C.B. 569 (providing that a co-owned joint-production arrangement may make the section 761 election).

176. See Madison Gas \& Elec. Co., 633 F.2d at 517 (finding that the joint venture qualified as a partnership, and that its pre-operational costs were therefore non-deductible "start-up costs of the partnership venture"). Section 195 requires taxpayers to capitalize start-up expenditures and then allows them to amortize such costs. I.R.C. § 195 (2000). Thus, if Madison Gas \& Electric Company is good law, Alpha would be required to capitalize the costs of formation and preoperating costs, even if section 709(b) is inapplicable because the arrangement is a qualified tax partnership.

177. See Gilford v. Comm'r, 201 F.2d 735, 736 (2d Cir. 1953) (holding that services required to maintain property in rental condition are not sufficient to create a tax partnership); Rev. Rul. 75-374, 1975-2 C.B. 261 (ruling that an arrangement that hires a third party to provide customary tenant services is not a tax partnership). Under these authorities, Beta and Zeta should be able to pay a manager to provide customary tenant services without converting the arrangement to a tax partnership. If that requires they pay for manager training, the amount should not be a start-up cost for Beta because Zeus Apartments is an expansion of Beta's apartment-renting business. See infra note 178 and accompanying text.

178. See Malmstedt v. Comm'r, 578 F.2d 520, 526-27 (4th Cir. 1978) (holding that a taxpayer who had previously developed residential property could deduct costs incurred in a failed commercial development); Briarcliff Candy Corp. v. Comm'r, 475 F.2d 775, 787 (2d Cir. 1973) (allowing a deduction for costs incurred to expand an existing business to different locations); York v. Comm'r, 261 F.2d 421, 422 (4th Cir. 1958) (holding that taxpayers who engaged in the "development, management, and improvement of real estate generally, but not including industrial properties" could deduct costs incurred to study industrial possibilities of other property; and holding that sharing the cost of the study with another did not alter the character of the expenditure as "that was but an economy").

179. The criteria used to assess whether the two arrangements are sufficiently different should reflect the purpose for the underlying statute. See Bradley T. Borden, The Like-Kind Exchange Equity Conundrum, 60 FLA. L. REv. (forthcoming 2008) (providing examples of absurd results that 
Based on its decision in Madison Gas \& Electric Co., the Seventh Circuit would treat Saturn Power Co. as a tax partnership because the arrangement comes within the substantive law definition of partnership under its interpretation of joint-profit motive. ${ }^{180}$ The court did not appear to consider whether its conclusion was correct from a policy perspective; ${ }^{181}$ it merely looked at the unclear definition of tax partnership and formulated a new interpretation of it. ${ }^{182}$ After holding that the arrangement was a tax partnership, the court felt bound to preclude the deduction of the pre-operation costs. ${ }^{183}$ The court should have considered whether the tax treatment of the arrangement should more fully reflect that of disregarded arrangements or that of tax partnerships in making its determination.

The structure of the arrangement in Madison Gas \& Electric Co. gave the members an undivided interest in the property, entitled the members to receive a share of power produced in kind, and required each member to pay a share of the arrangement's operating costs. ${ }^{184}$ The taxpayer in the case joined the arrangement to obtain power needed to service the growing population within the area it was "required to furnish [with] reasonably adequate service and facilities... at rates found reasonable and just by the PSC." " 185 Prior to joining that arrangement, the taxpayer had kept up with the increasing power demand "by expanding the generating capacity of its facilities, contracting for the purchase and sale of excess electrical power, interconnecting transmission facilities with those of other Wisconsin utilities, and finally by building and operating additional facilities in conjunction with other utilities."186 The facts appear to demonstrate a clear business expansion, and therefore, the costs incurred prior to the operation should be deductible. ${ }^{187}$

obtain if criteria for comparison are not based on legitimate standards).

180. See Borden, supra note 5, at 989-91 (revealing that the Seventh Circuit found the co-owned joint-production arrangement had the requisite joint-profit motive and was, therefore, a partnership).

181. See Madison Gas \& Elec. Co., 633 F.2d at 517 ("At bottom, MGE's position is that it is not sound policy to treat the entity here as a partnership. But we are not free to rewrite the tax laws, whatever the merits of MGE's position.").

182. See Borden, supra note 5, at 1017-23 (demonstrating the definition of profit the Seventh Circuit used produces an unworkable definition of tax partnership under a policy analysis).

183. See Madison Gas \& Elec. Co., 633 F.2d at 517 ("Under the Internal Revenue Code the joint venture here is a partnership and the expenses were non-deductible, pre-operational start-up costs of the partnership venture.").

184. See id. at 513-14.

185. Id. at 513 .

186. Id. In fact, all of the members were already in the business of selling electricity before they formed the arrangement. $I d$. at 517.

187. See supra note 178. 
The court's rationale (which the author questions) ${ }^{188}$ for holding that the arrangement in Madison Gas \& Electric Co. was a tax partnership should have no bearing on its decision regarding the deductibility of the arrangement's pre-operating costs. Each member of the arrangement joined the arrangement for the sole purpose of expanding existing businesses. ${ }^{189}$ They each owned an interest in the facilities, and they each took power from the facilities to sell to customers. ${ }^{190}$ The arrangement was merely another way for the members to obtain electrical power needed to expand existing business operations. The mere fact that the members were able to share economies of scale by joining together should not have obscured the fact that they each acted to expand existing businesses. ${ }^{191}$ Because the arrangement was not established for the sake of the arrangement, but for the individual purposes of the arrangement's members, the court should have treated the members of the arrangement as though they were members of a disregarded arrangement. Thus, policy suggests that for purposes of determining the deductibility of pre-operating costs, qualified tax partnerships should be subject to the rules that govern disregarded arrangements.

\section{Gain/Loss Characterization}

The character of gain or loss recognized on the disposition of property depends upon the purpose and amount of time for which the owner holds the property. ${ }^{192}$ The following example demonstrates the potential result if the gain/loss characterization Code provisions recognize qualified tax partnerships. Clyde and Devon co-own a piece of raw land in a disregarded arrangement. Clyde and Devon do not have any intention to develop the property, do not advertise it for resale together, and do not own any other property together. Clyde is a dentist and purchased his share of the land to hold as an investment. Clyde's

188. See Borden, supra note 5, at 1017-23.

189. See Madison Gas \& Elec. Co., 633 F.2d at 517 (noting each participant's possible motive to expand existing business).

190. See id. at 513 (stating that each member used the facilities' power as they did the power produced by their own facilities).

191. See Madison Gas \& Elec. Co. v. Comm'r, 72 T.C. 521, 565 (1979) ("In the instant case, the economies of scale involved in a jointly owned nuclear power plant were the reason for the joint venture which we have held to be a partnership for Federal income tax purposes."), aff'd, 633 F.2d 512 (7th Cir. 1980).

192. See I.R.C. § $1(\mathrm{~h})(1)(\mathrm{C})$ (2000) (providing favorable tax rates to adjusted net capital gain); $i d . \S 1222(11)$ (defining net capital gain as the excess of net long-term capital gain over net shortterm capital loss). 
interest in the property is a capital asset to him. ${ }^{193}$ If Clyde holds the interest for more than one year, any gain he recognizes on the disposition of the interest should be subject to favorable long-term capital gains rates.

Devon on the other hand, is a dealer in real property. He purchased the interest in the raw land as part of his inventory. He actively markets the interest. Therefore the interest is not a capital asset to him, ${ }^{194}$ and any gain he recognizes on the disposition of the interest should be taxed at ordinary income rates. ${ }^{195}$

If this arrangement between Clyde and Devon were a tax partnership, each individual would take a basis in his respective partnership interest, ${ }^{196}$ and the partnership would take a basis in the raw land. ${ }^{197}$ The partnership would have to recognize any gain or loss on the disposition of the property ${ }^{198}$ (which it would allocate to Clyde and Devon), ${ }^{199}$ and Clyde and Devon would have to recognize gain on the sale of their respective partnership interests if either were to sell his interest. ${ }^{200}$ The character of the gain or loss on the partnership's disposition of the property would be determined at the partnership level. ${ }^{201}$ Thus, if the partnership were to sell the property and recognize long-term capital gain, that character would flow through to both Clyde and Devon. That result is different than if the arrangement was disregarded.

If instead of being a tax partnership or disregarded arrangement, the arrangement were a qualified tax partnership, ${ }^{202}$ the law does not specifically provide which rules would apply. The existence of a rule in subchapter $\mathrm{K}$ providing that character of gain or loss is determined at partnership level and flows through to the partners indicates that, even in the tax partnership context, the appropriate rule with respect to tax partnerships would be unclear without specific legislation. In the absence of a clear rule, member-level determination is appropriate. Without subchapter $\mathrm{K}$, the members of the arrangement would directly own their interests in the property for tax purposes. Determining the

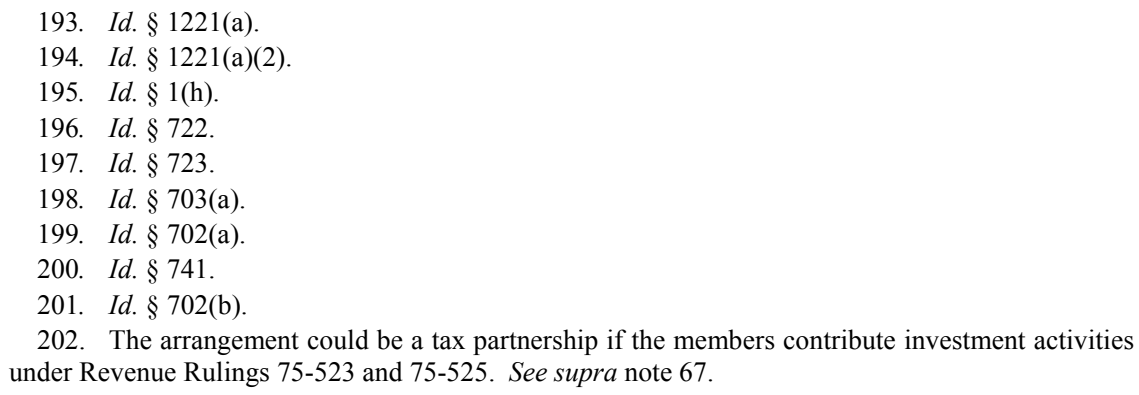


character of gain or loss at the entity level would be inconsistent with that ownership. The members would have difficulty determining whether Clyde's or Devon's holding purpose and period should determine the character of the gain at the arrangement level. Thus, the gain/loss character provisions of the Code should disregard qualified tax partnerships, even if they are not interdependent with section 761 .

In sum, comparing qualified tax partnerships to tax partnerships and disregarded arrangements reveals that the difference between qualified tax partnerships and tax partnerships justifies treating them differently. In particular, the Bentex Oil hardship alleviation purpose justifies the different tax treatment. ${ }^{203}$ The comparison does not appear to reveal a justification for treating qualified tax partnerships and disregarded arrangements differently. The following diagram depicts the comparison of qualified tax partnerships to tax partnerships and disregarded arrangements.

\section{Comparative Justification of Qualified Tax Partnerships}

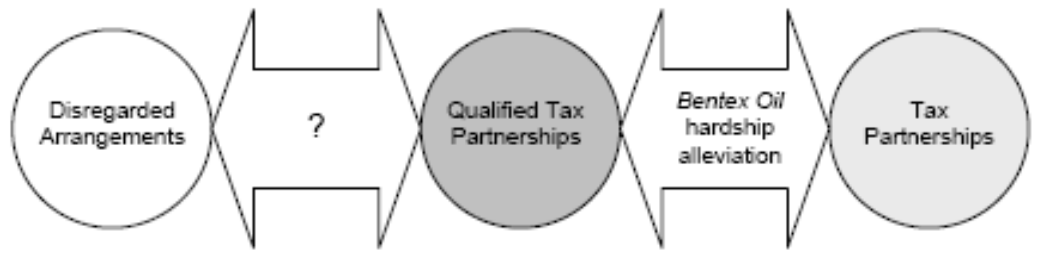

\section{PROPOSALS}

The above analysis demonstrates that the current qualified tax partnership classification rules are flawed. It also demonstrates that the interdependence test produces inconsistent and inappropriate results. Therefore, the system is ripe for repair. The goal of modifications should be to group arrangements in a manner that rules applicable to the arrangements within each group are supported by sound tax policy considerations.

A universal solution would require narrowing the definition of tax partnership to exclude those arrangements that currently come within the definition of qualified tax partnership. If that solution is not palatable for

203. See supra notes $146-53$ and accompanying text. 
some reason, Treasury should expand the definition of qualified tax partnership. Provisions outside subchapter $\mathrm{K}$ should apply on a property-specific or activity-specific basis, not under the interdependence test. Finally, Congress should eliminate the election out of subchapter K and make the exemption mandatory for any arrangement that comes within the modified definition of qualified tax partnership.

\section{A. Narrow the Definition of Tax Partnership}

Narrowing the definition of tax partnership would simplify the tax entity classification by eliminating one tax entity. More importantly, it would serve significant policy objectives. The current broad definition of tax partnership includes arrangements that cannot compute income at the entity level. ${ }^{204}$ The definition of tax partnership should be narrowed to exclude those arrangements. This narrowing would exclude co-owned joint-production arrangements from the definition of tax partnership.

The definition of tax partnership also includes arrangements that have no need for subchapter K. For example, an arrangement that only has investment income should be required to allocate that income to its members based on each member's interest in the arrangement's underlying assets. Investment-income arrangements should not be given the opportunity to use the partnership tax allocation rules. ${ }^{205}$ Narrowing the definition of tax partnership to exclude such arrangements would exclude investment clubs from the definition of tax partnership.

The definition of tax partnership, if modified to reflect these proposals, would provide "a tax partnership is two or more persons, at least one of whom provides significant services, who have (or will have) common gross income."206 This definition would exclude co-owned joint-production arrangements because such arrangements do not have gross income. Instead, the members have separate, not common, gross income from the arrangement. The proposed definition would exclude investment clubs because none of the members perform significant services under the section 162 definition of business activity. Although this proposed definition would serve several policy objectives, it is not the current law.

204. See Borden, supra note 5, at 1018-22.

205. See id. at 970.

206. See id. at 1028 (emphasis in original omitted). 


\section{B. Alternatively, Expand the Definition of Qualified Tax Partnership}

Expanding the definition of qualified tax partnership is an alternative way to accomplish policy objectives. To the extent the section 761 regulations are valid, ${ }^{207}$ they create a fairly narrow definition of qualified tax partnership. The two definitional elements of qualified tax partnerships that unduly narrow the definition are (1) the requirement that members of a qualified tax partnership co-own property, ${ }^{208}$ and (2) the requirement that they be able to alienate their interests. ${ }^{209}$ Tax policy does not support either requirement. Nor are they found in the statutory definitions of qualified tax partnership. ${ }^{210}$ The restrictive nature of those provisions prevents several arrangements from qualifying for subchapter $\mathrm{K}$ exemption. The result is that some arrangements are subject to subchapter $\mathrm{K}$ in the face of contrary policy. Therefore, Treasury should eliminate both requirements.

\section{Eliminate the State-Law Classification Requirement}

The requirement that the property owners own property as co-owners prevents them from holding property indirectly in a state-law entity. This appears to be either an adoption of the estoppel test, which courts use to prevent taxpayers from disclaiming tax partnership classification, ${ }^{211}$ or a relic from rulings and cases that cling to state-law classification when considering whether an arrangement is a tax partnership. ${ }^{212}$ The Supreme Court has ruled that state-law classification

207. Perhaps one could successfully argue that the regulations are invalid because they do not reasonably interpret section 761 . The co-ownership prohibition and alienability requirement are not found in the statutory definition of qualified tax partnership and do not reflect the current definition of tax partnership. Thus, the regulations may be an unreasonable interpretation of the statutory definition.

208. Treas. Reg. $\S \S 1.761-2(a)(2)(i)$ to 2(a)(3)(i) (as amended in 1995).

209. Id. $\S \S 1.761-2(\mathrm{a})(2)(\mathrm{ii})$ to $2(\mathrm{a})(3)(\mathrm{ii})$.

210. I.R.C. $\S 761(\mathrm{a})(1),(2)$ (2000).

211. See, e.g., Maletis v. United States, 200 F.2d 97, 97-98 (9th Cir. 1952) (taking into consideration the state-law classification of an arrangement to estop the taxpayer from disclaiming tax partnership classification); see also Borden, supra note 5, at 1000-01.

212. See, e.g., Joe Balestrieri \& Co. v. Comm'r, 177 F.2d 867, 871 (9th Cir. 1949) (holding the arrangement was not a tax partnership because it did not satisfy the California definition of joint venture); Comm'r v. Olds, 60 F.2d 252, 254 (6th Cir. 1932) (relying upon Michigan law); Copeland v. Ratterree, Civil No. 5215, 1957 U.S. Dist. LEXIS 4556, *12 (N.D.N.Y. July 23, 1957) (reasoning that because the arrangement was made in Vermont it should be classified according to Vermont laws); Estate of Appleby v. Comm'r, 41 B.T.A. 18, 20 (1940) (holding arrangement not a tax partnership based on tenancy-in-common status under state law), aff'd, 123 F.2d 700 (2d Cir. 1941), see also Estate of Strangi v. Comm'r, 115 T.C. 478, 486 (2000) (relying upon state law classification to hold that a tax partnership existed for purposes of applying the minority discount to determine the 
does not govern tax partnership classification, ${ }^{213}$ and Treasury adopted that rule in the check-the-box regulations. ${ }^{214}$ Thus, state-law classification does not determine whether an arrangement is a tax partnership. The reason for disregarding state law in the definition of tax partnership also applies to the definition of qualified tax partnership. Applying state law as a test for tax partnership and qualified tax partnership creates administrative complexity and inequity. ${ }^{215}$ Because each state's definition of partnership may be different, applying a statelaw test to the definition of qualified tax partnership requires the IRS and taxpayers to know the laws of the fifty states to determine whether arrangements can be qualified tax partnerships.

A definition that relies upon state law can produce different results for similarly situated taxpayers. For example, a co-owned jointproduction arrangement could be a partnership under the laws of State X, while an identical co-owned joint-production arrangement could be a tenancy-in-common in State Y. Other than the state-law classification of the arrangements, the two arrangements are identical. Nonetheless, under the current definition of qualified tax partnership, only the arrangement in State $\mathrm{Y}$ would qualify for the section 761 election. Because the state-law test could treat two similar arrangements differently, the state-law test is inequitable. ${ }^{216}$

Furthermore, the state-law test does not further the purpose of qualified tax partnerships. Recall Congress enacted section 761 to alleviate the hardships caused by Bentex Oil Corp. ${ }^{217}$ Madison Gas \& Electric Co. provided that an arrangement that cannot compute taxable income at the entity level (at least not without considerable difficulty) is a tax partnership. ${ }^{218}$ Section 761 allows such arrangements to elect out

value of a gift), aff'd in part, rev'd in part on other grounds, 293 F.3d 279 (5th Cir. 2002); Powell v. Comm'r, 26 T.C.M. (CCH) 161, 164 (1967) (finding the arrangement was a tenancy-in-common under state law and, therefore, not a tax partnership); Rev. Rul. 2004-86, 2004-2 C.B. 191 (considering state-law classification to determine whether a Delaware Statutory Trust is a separate entity).

213. See Comm'r v. Tower, 327 U.S. 280, 288 (1946) (rejecting the state law classification, the Supreme Court stated, "[b]ut Michigan cannot by its decision and laws governing questions over which it has final say, also decide issues of federal tax law and thus hamper the effective enforcement of a valid federal tax levied against earned income").

214. Treas. Reg. § 301.7701-1(a)(1) (as amended in 2006) (defining separate entity to be "a matter of federal tax law and does not depend on whether the organization is recognized as an entity under local law").

215. See Borden, supra note 5, at 1010-11 (demonstrating that the state-law test is uncertain and violates equity and neutrality).

216. See id. at 1010-11 (explaining how the state-law test treats relationships differently, even when the underlying economic arrangement remains the same).

217. See supra text accompanying notes 145-46.

218. See Madison Gas \& Elec. Co. v. Comm'r, 633 F.2d 512, 517 (7th Cir. 1980) (holding that 
of subchapter $\mathrm{K}$ instead of performing the difficult task of computing taxable income at the entity level. The existence of a state-law entity should not affect the arrangement's ability to compute income at the arrangement level. Thus, the state-law test in the regulations frustrates the purposes of section 761 .

\section{Eliminate the Alienability Requirement}

The alienability requirement in the regulatory definition of investment qualified tax partnership appears to come from substantive law. Under substantive law, a characteristic of a tenancy-in-common arrangement is the co-owner's right to alienate the interest in the property. ${ }^{219}$ Treasury appears to incorporate that characteristic of a tenancy-in-common into the definition of investment qualified tax partnership. The right to alienate is derivative of the definition of partnership, it is not determinative of the definition. ${ }^{220}$ The motive for such inclusion may simply be that Treasury believed that an arrangement should not be able to elect out of subchapter $\mathrm{K}$ unless it possesses the alienability characteristic of a tenancy-in-common. Policy does not, however, support that position.

As with the state-law entity requirement, the alienability requirement undermines the purpose of section 761 and creates administrative inconvenience and potential inequities. Whether a party can alienate the underlying property of an arrangement does not affect the arrangement's ability to compute taxable income at the entity level. If the arrangement distributes property in kind it will not be able to compute entity-level income without considerable difficulty, if at all. Determining whether the members of an arrangement can transfer their respective interests in

"under the Internal Revenue Code the joint venture [was] a partnership and the expenses were nondeductible, pre-operational start-up costs of the partnership ventures").

219. See Floyd R. Mechem, Elements of the Law of Partnership $\S 11$, at 15-16 (2d ed. 1920) (showing how co-ownership differs from partnership by providing a contemporary list which includes: "1. Co-ownership is not necessarily the result of an agreement to create it, while partnership is. 2. Co-ownership does not necessarily involve community of profit or loss, while partnership does. 3. One co-owner may, without the consent of the others, assign his interest in such a way that his assignee will assume his relations to the other co-owners, but one partner cannot do this. 4. One co-owner is not as such the agent of the others, while a partner is. 5. One co-owner has no lien on the common property for expenses or outlays, or for what may be due from the others as their share of a common debt, while a partner has such a lien" (footnotes omitted)).

220. The question of alienability would arise if a coowner attempted to sell the interest unilaterally. It could also arise if a co-owner's creditor attempted to foreclose on an interest. In either situation, the alienability of the interest would turn on whether the arrangement was a partnership or a tenancy-in-common. See William Draper Lewis, The Uniform Partnership Act-A Reply to Mr. Crane's Criticism, 29 HARV. L. REV. 158, 162-63 (1915) (discussing the significance of tenancy-in-common classification). 
the underlying property requires a determination of whether the arrangement is a state-law partnership or a state-law tenancy-in-common. Because the definition of partnership and tenancy-in-common varies from state to state and the determination within any state may be difficult, requiring such a determination creates an administrative inconvenience. ${ }^{221}$ The different possible results in different states also may create inequity. ${ }^{222}$ Treasury should therefore eliminate the state-law classification requirement and the alienability requirement, both of which are contrary to the Bentex Oil Corp. hardship alleviation purpose.

\section{Clarify the Business-Activity Prohibition}

Treasury should clearly define the third element of the definition of investment qualified tax partnership. That requirement currently prohibits an investment qualified tax partnership from actively conducting business. ${ }^{223}$ To have effect, that requirement must narrow the definition of tax partnership. That means it must apply to arrangements that are tax partnerships and add an element to the definition of tax partnership. $^{224}$ With no clear indication of its application, speculation is the only means of determining its application.

To have effect, the business-activity prohibition must apply to arrangements that are tax partnerships but have no business activity. That concept almost seems counterintuitive because courts often refer to business activity in deciding whether an arrangement is a tax partnership. ${ }^{225}$ Nonetheless, some arrangements that conduct business activity do not come within the definition. ${ }^{226}$ In fact, a close examination of cases and rulings reveals that courts and the IRS are mostly concerned about the type and source of activity when considering the definition of tax partnership. ${ }^{227}$ Those cases and rulings provide that co-ownership arrangements may hire a manager to provide customary tenant services

\footnotetext{
221. See supra text accompanying note 215 .

222. See supra text accompanying note 216 .

223. Treas. Reg. §1.761-2(a)(2)(iii) (as amended in 1995).

224. See supra text accompanying notes $49-57$.

225. See, e.g., Cusick v. Comm'r, 76 T.C.M. (CCH) 241 (1998) ("The regulations and relevant case law indicate that the distinction between mere coowners and coowners who are engaged in a partnership lies in the degree of business activity of the coowners or their agents." (citations omitted)).

226. See, e.g., Gilford v. Comm'r, 201 F.2d 735, 736 (2d Cir. 1953) (holding that business activity did not cause arrangement to be a tax partnership, and the loss from the sale of property was a section 1231 loss); Rev. Rul. 75-374, 1975-2 C.B. 261 (ruling that a co-ownership was not a tax partnership, even though the members hired a manager to provide customary tenant services).

227. See Borden, supra note 5, at 992-95 (discussing the type-of-activity test).
} 
without becoming tax partnerships. ${ }^{228}$ That leeway allows arrangements to provide a significant amount of services - an amount that would satisfy the trade or business requirement in section 162-without being tax partnerships. ${ }^{229}$ Because the definition of tax partnership excludes such arrangements, the business-activity prohibition in the definition of qualified tax partnership must not refer to such arrangements.

Instead, the business-activity prohibition in the definition of qualified tax partnership must apply to arrangements that provide no business activity but are nonetheless tax partnerships. That conclusion indicates that the definition of tax partnership must consider factors other than the degree of business activity the arrangement provides. A possible interpretation is that an investment club, or similar arrangement, may be a tax partnership if the members contribute investment activities to the arrangement. Under the source-of-activities test, an arrangement should be a tax partnership if the members contribute services to the arrangement. ${ }^{230}$ An investment club, for example, would be a tax partnership because its members contribute investment services. It would not, however, conduct business, so it could come within the regulatory definition of qualified tax partnership. Tax policy supports a definition that exempts such arrangements from subchapter K.

Investment activities should not generate income (they merely support the property's income-producing function). ${ }^{231}$ If the definition of investment qualified tax partnership limits the members' activities to investment activities, the arrangement's sole source of income would be the arrangement's property. The members' services would not produce income. That being the case, the arrangement should be able to allocate the income and expenses to the members of the arrangement based on

228. See supra note 226.

229. See Borden, supra note 5, at 993-94.

230. See, e.g., Cusick, 76 T.C.M. (CCH) at 241 (holding that arrangement was a tax partnership even though members contributed only customary tenant services); Bergford v. Comm'r, 12 F.3d 166, 166 (9th Cir. 1993) (financed, purchased, and leased equipment); Alhouse v. Comm'r, 62 T.C.M. (CCH) 1678, 1679 (1991) (sold, purchased, and leased equipment); Bussing v. Comm'r, 89 T.C. 1050, 1061 (1987) (leased, sold, and encumbered equipment); Bussing v. Comm'r, 88 T.C. 449 , 451 (1987) (performed maintenance and repair).

231. Business activities, on the other hand, should generate income (the activities increase rental income, improve the value of property, or contribute to the property's ultimate disposition). See Borden, supra note 5, at 995. By treating the income from the sale of dealer property as ordinary income, the tax system treats the gain as derived from the activities of the owners, not from the investment in the property. See Marjorie E. Kornhauser, The Origins of Capital Gains Taxation: What's Law Got To Do With It?, 39 Sw. L.J. 869, 890 (1985) ("The distinction between investor and businessman is critical here, as it was in Britain, because the former held his capital to produce income in the form of rents, dividends, or interest; the latter used his capital to buy and sell assets such that the act of buying and selling produced income in the form of the gains realized from the increased value."). 
their proportionate ownership in the arrangement's property. Thus, the arrangement would not be required to compute taxable income at the partnership level and would not need the partnership tax allocation rules to allocate the arrangement's tax items to the members. Therefore, such arrangements should not be subject to subchapter K.

The business-activity prohibition is sensible if it exempts investment clubs and similar arrangements from subchapter K. Treasury should modify the definition of investment qualified tax partnership to reflect this interpretation of the business-activity prohibition. The definition should clearly provide that it applies to arrangements that are tax partnerships because the members contribute investment activities to the arrangement. The arrangement will be a qualified tax partnership, however, if the member's contributed services are limited to investment activities, and do not include business activities. ${ }^{232}$ Treasury could further clarify the rule by defining investment activities as activities that do not come within the section 162 definition of business activity.

\section{Retain the In-Kind Distribution Requirement}

Tax policy supports excluding co-owned joint-production arrangements from subchapter $\mathrm{K}$ if the members individually sell the arrangement's product. In such arrangements, individual members, not the arrangement, realize gross income from the sale of the product. Such arrangements have no taxable income and should not be subject to the partnership tax rules. ${ }^{233}$ Nonetheless, the broad definition of tax partnership appears to include such arrangements. ${ }^{234}$ The definition of production qualified tax partnership effectively and appropriately exempts co-owned joint-production arrangements from subchapter $\mathrm{K}$. Thus, that provision needs no modification.

232. Thus, the test would apply the source-of-activity test at the tax partnership level and the type-of-activity test at the qualified tax partnership level. See Borden, supra note 5, at 992-98 (describing the type-of-activity test and the source-of-activity test). This conclusion is different from any of the possible alternative treatments the Author presented in an earlier article. See Borden, supra note 32, at 60-61. The conclusion in this Article represents the result of additional thought on the theory of qualified tax partnerships and appears to enjoy greater theoretical support than the other alternatives.

233. See Borden, supra note 5, at 1017-23.

234. See, e.g., Madison Gas \& Elec. Co. v. Comm'r, 633 F.2d 512, 517 (7th Cir. 1980). 


\section{Replace the Interdependence Test with a Property-Specific Test}

As demonstrated above, the interdependence test works only to the extent it requires interdependent Code sections to disregard qualified tax partnerships. ${ }^{235}$ To the extent the interdependence test may require noninterdependent Code sections to recognize qualified tax partnerships, the test often fails. The discussion above demonstrates that property-specific Code sections may recognize qualified tax partnerships. ${ }^{236}$ Other provisions, such as the gain/loss characterization provisions and preoperating costs capitalization rules, should disregard qualified tax partnerships. ${ }^{237}$ Finally, other provisions, such as the definition of selfemployment income, are unaffected by classifying an arrangement as a qualified tax partnership. ${ }^{238}$ Thus, only property-specific Code sections should recognize qualified tax partnerships. The interdependence test should not uniformly require non-interdependent Code sections to recognize qualified tax partnerships.

\section{Eliminate the Election out of Subchapter $K$}

Tax policy does not support elective tax treatment. Elections complicate tax planning because taxpayers must hire an advisor to identify the tax treatment available with and without making the election. $^{239}$ Elections create inequity because taxpayers who are otherwise similarly situated will be subject to different tax rules if one makes the election and the other does not. Finally, if tax policy supports treating some arrangements as qualified tax partnerships, it supports treating all similar arrangements as qualified tax partnerships. For example, tax policy supports exempting production qualified tax partnerships from subchapter $\mathrm{K}$ because such arrangements cannot compute taxable income. ${ }^{240}$ Precisely because such arrangements cannot compute taxable income, they should not be subject to subchapter K. In fact, policy does not support applying subchapter $\mathrm{K}$ to such provisions. Therefore, the qualified tax partnership elective regime should be

\footnotetext{
235. See supra Part IV.B.

236. See supra Part IV.B.1.

237. See supra Part V.B.3-4.

238. See supra Part V.B.2.

239. See Dean, supra note 110 , at $430-32$.

240. See Borden, supra note 5, at 1017-23.
} 
eliminated. Any arrangement that comes within the definition of qualified tax partnership should be so classified.

\section{CONCLUSION}

Qualified tax partnerships are definitely a part of the U.S. tax system. Under the current arrangement classification structure, they serve an important function. They exempt from subchapter $\mathrm{K}$ arrangements that policy suggests should not be subject to the partnership tax accounting and reporting rules. Nonetheless, the importance of qualified tax partnerships is derived from a faulty definition of tax partnership. Properly modifying the definition of tax partnership would eliminate the need for qualified tax partnerships. Absent such a modification, Treasury should modify the definition of qualified tax partnership to reflect sound tax policy. Furthermore, the interdependence test used to determine the applicability of Code sections outside of subchapter $\mathrm{K}$ should only require interdependent Code sections to disregard qualified tax partnerships; it should not require non-interdependent Code sections to recognize them.

The tax literature largely ignores qualified tax partnerships. That neglect is not justified. Qualified tax partnership classification can significantly affect a taxpayer's tax liability, increasing the federal government's revenue. Continuing to neglect qualified tax partnerships could lead to haphazard rules in this area of the law. Haphazard rules will most likely fail to reflect sound tax policy. Lawmakers should consider the theory and policy of qualified tax partnerships and preempt the area by creating sound rules. 